\title{
Evidence for Past Subduction Earthquakes at a Plate Boundary with Widespread Upper Plate Faulting: Southern Hikurangi Margin, New Zealand
}

\author{
by Kate J. Clark, Bruce W. Hayward, Ursula A. Cochran, Laura M. Wallace, \\ William L. Power, and Ashwaq T. Sabaa
}

\begin{abstract}
At the southern Hikurangi margin, New Zealand, we use salt marsh stratigraphy, sedimentology, micropaleontology, and radiocarbon dating to document evidence of two earthquakes producing coseismic subsidence and (in one case) a tsunami over the past 1000 yrs. The earthquake at 520-470 yrs before present (B.P.) produced $0.25 \pm 0.1 \mathrm{~m}$ of subsidence at Big Lagoon. The earthquake at $880-800$ yrs B.P. produced $0.45 \pm 0.1 \mathrm{~m}$ of subsidence at Big Lagoon and was accompanied by a tsunami that inundated $\geq 360 \mathrm{~m}$ inland with a probable height of $\geq 3.3 \mathrm{~m}$. Distinguishing the effects of upper plate faulting from plate interface earthquakes is a significant challenge at this margin. We use correlation with regional upper plate paleoearthquake chronologies and elastic dislocation modeling to determine that the most likely cause of the subsidence and tsunami events is subduction interface rupture, although the older event may have been a synchronous subduction interface and upper plate fault rupture. The southern Hikurangi margin has had no significant $(\mathbf{M}>6.5)$ documented subduction interface earthquakes in historic times, and previous assumptions that this margin segment is prone to rupture in large to great earthquakes were based on seismic and geodetic evidence of strong contemporary plate coupling. This is the first geologic evidence to confirm that the southern Hikurangi margin ruptures in large earthquakes. The relatively short-time interval between the two subduction earthquakes ( $350 \mathrm{yrs})$ is shorter than in current seismic-hazard models.
\end{abstract}

Online Material: Historical accounts, description of vertical deformation, core names, foraminifera census and abundance, diatom census, modern analog samples, map of cores collected, stratigraphic correlation diagram for all cores, and detailed core logs.

\section{Introduction}

The Hikurangi subduction margin is one of the few circum-Pacific subduction zones that has not had a great $(\mathbf{M}>8)$ subduction interface earthquake in historic times (post $\sim$ A.D. 1840, Wallace et al., 2009), and it has a less complete record of prehistoric subduction earthquakes than many other margins (e.g., Cascadia, Atwater, 1987; Japan, Nanayama et al., 2003; Chile, Cisternas et al., 2005; Alaska, Shennan, Barlow, et al., 2014). There is evidence for subduction earthquakes on the central Hikurangi margin at $~ 5550$ and $~ 7100$ yrs before present (B.P.) (Cochran et al., 2006) and possibly four younger events at 4200, 3000, 1600, and 600 yrs B.P. (Hayward et al., 2006), but notably there is no evidence for prehistoric subduction earthquakes on the northern and southern Hikurangi margin (Fig. 1a). This study focuses on the southern Hikurangi margin, where the contemporary geodetic rates suggest the plate interface is currently locked and accumulating elastic strain (Fig. 1a, Wallace et al., 2004, 2009), thus it is considered to potentially pose a greater hazard than the rest of the margin (Stirling et al., 2012).

Part of the challenge in searching for evidence of prehistoric subduction earthquakes on the Hikurangi margin is the ubiquitous upper plate faulting (Fig. 1). Subduction margins where geologic records of multiple prehistoric subduction earthquakes have been obtained do not typically display the complexity of upper plate faulting present in the southern Hikurangi margin. At such margins, paleoearthquake recurrence estimates come from the geological record of coastal 
(a)

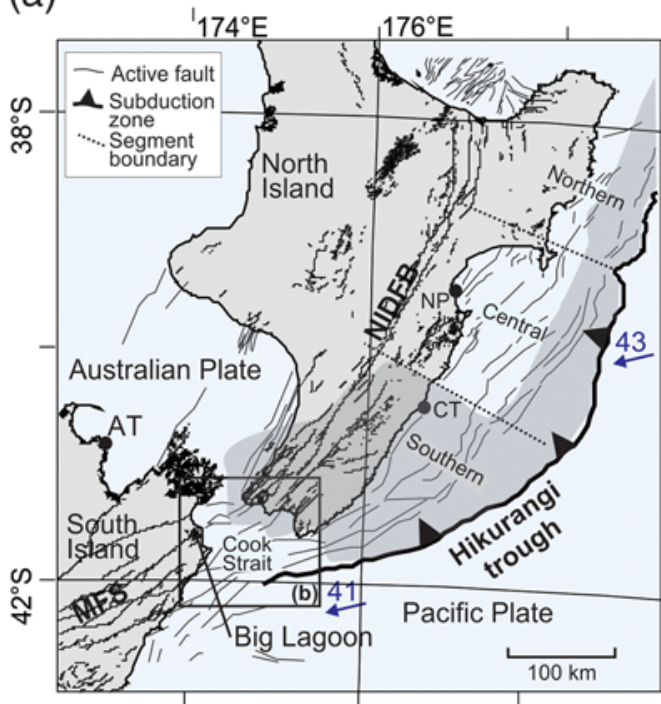

(b)

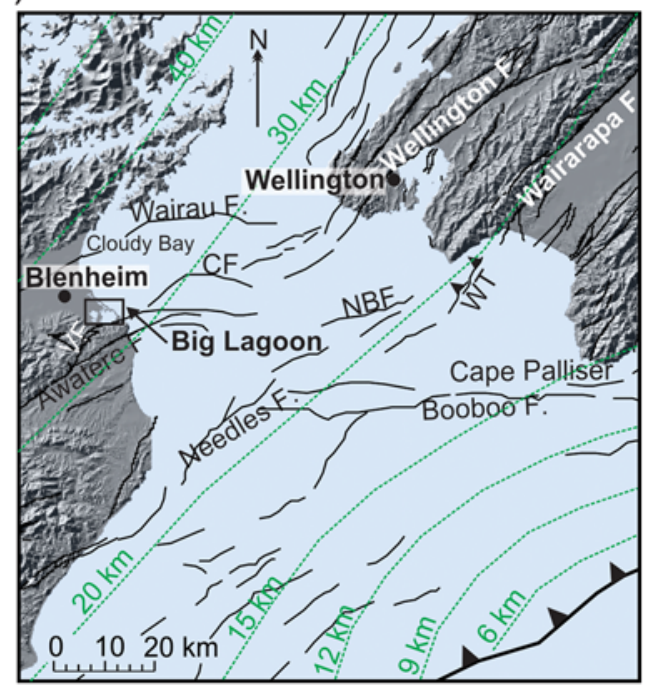

Figure 1. (a) Tectonic setting of the Hikurangi margin. The dotted lines show the approximate boundaries between the southern central and northern segments of the Hikurangi margin. Onshore active faults are from the New Zealand Active Faults Database (see Data and Resources). Offshore active fault models are from Litchfield et al. (2014). The zone of strong plate interface coupling (slip deficit $>20 \mathrm{~mm} / \mathrm{yr}$ ) is shown in shaded gray (Wallace and Beavan, 2010). Vectors show Pacific-Australian plate motion (mm/yr). MFS, Marlborough fault system; AT, Abel Tasman National Park; NIDFB, North Island dextral fault belt; NP, Napier; CT, Cape Turnagain. (b) The Cook Strait region and the Big Lagoon study site. Offshore active faults in the Cook Strait region are from Pondard and Barnes (2010). The dashed contour lines show plate interface depth (Williams et al., 2013). CF, Cloudy fault; VF, Vernon fault; NBF, Nicholson Bank fault; WT, Wharekauhau thrust. The color version of this figure is available only in the electronic edition.

uplift, subsidence, and/or paleotsunami (e.g., Cascadia, Witter et al., 2003; Kelsey et al., 2005; Nelson et al., 2006; Chile, Cisternas et al., 2005; Sumatra, Sieh et al., 2008). There are, however, examples of subduction margins at which there is significant upper plate faulting (e.g., at transitional plate boundaries and areas of microplate collision, such as Alaska, Gulick et al., 2007) and when subduction of buoyant masses such as seamounts and plateaus produces intense upper plate deformation (Central America, Sak et al., 2009). Such subduction margins still host subduction interface earthquakes, but upper plate faults severely complicate the search for unequivocal geological evidence of megathrust ruptures (e.g., Shennan, Bruhn, et al., 2014).

The ability of upper plate faults to produce coastal deformation of a similar nature to subduction earthquakes has been demonstrated by two historical earthquakes along the Hikurangi margin. The A.D. $1855 M_{\mathrm{w}} 8.1-8.2$ Wairarapa earthquake on the oblique dextral Wairarapa fault caused up to $6.4 \mathrm{~m}$ of coastal uplift and tsunami runup heights of up to $10 \mathrm{~m}$ on the south Wellington Coast (McSaveney et al., 2006). The $1931 M_{\mathrm{w}} 7.8$ Napier earthquake on a reverse-dextral blind fault produced up to $2.7 \mathrm{~m}$ of coastal uplift and $0.7 \mathrm{~m}$ of coastal subsidence near Napier (Hull, 1990). There are also global examples of great subduction earthquakes that have triggered synchronous rupture of upper plate faults (Plafker, 1967; Melnick et al., 2012), which further complicate the process of differentiating the evidence of subduction earthquakes from upper plate fault earthquakes.
The southern Hikurangi margin has a greater density of active upper plate faults than the rest of the Hikurangi margin (Fig. 1, Litchfield et al., 2014) and contains a rich record of coastal neotectonics (Pillans and Huber, 1995; McSaveney et al., 2006; Cochran et al., 2007; Hayward, Grenfell, Sabaa, Kay, et al., 2010; Berryman et al., 2011; Clark, Hayward, et al., 2011). However, to date all evidence of tectonic coastal deformation (mostly in the form of marine terrace uplift) has been attributed to earthquakes on upper plate faults, and no evidence of subduction earthquakes has been described. Here, we document evidence of two coseismic subsidence events, one accompanied by a tsunami, from a coastal lagoon called Big Lagoon, near Blenheim, on the southern Hikurangi margin. We show that the coseismic subsidence is consistent with rupture of the southern Hikurangi margin in a subduction earthquake, and that this subsidence is unlikely to have been caused by rupture on an upper plate fault. This is the first evidence that the southern Hikurangi margin ruptures in large to great earthquakes, and the relatively shorttime interval of $\sim 350$ yrs between the two events has significant implications for seismic hazard in New Zealand.

\section{Tectonic Setting and Historical Seismicity along the Southern Hikurangi Margin}

The southern Hikurangi margin underlies the southern North Island and northeastern South Island of New Zealand and it is characterized by oblique convergence between the Australian and Pacific plates (Fig. 1). The southern part 
(beneath Cook Strait and the northern South Island) is a zone of transition between convergence and continental transpression (Wallace et al., 2012). The fore-arc structure is dominated by transpressional northeast-striking dextral strike-slip faults, known as the North Island dextral fault belt and the Marlborough fault system (Fig. 1). The offshore accretionary wedge is $\sim 100 \mathrm{~km}$ wide adjacent to the lower North Island and narrows rapidly toward the south (Barnes and Mercier de Lepinay, 1997; Barnes et al., 1998).

The plate interface dips westward beneath the southern North Island and northeastern South Island and lies at approximately $25 \mathrm{~km}$ depth beneath Wellington and Blenheim (Fig. 1, Williams et al., 2013). Geodetic data show the plate interface beneath the southern North Island is currently interseismically coupled (Fig. 1; Wallace et al., 2012) and accumulating a slip rate deficit of $20-25 \mathrm{~mm} / \mathrm{yr}$. The strongly coupled patch on the plate interface from Cook Strait to Cape Turnagain has been suggested by Wallace et al. (2009) as a likely rupture area for an $M_{\mathrm{w}} 8.5-8.7$ plate interface earthquake. Recent seismicity patterns also correlate with the distribution of high interseismic coupling (Reyners and Eberhart-Phillips, 2009) and long-term geologic data indicate permanent shortening in the upper plate over the past 5 my, accounting for no more than $20 \%$ of the margin-normal plate convergence; the remaining $80 \%$ or more is assumed to be accommodated by slip on the subduction interface (Nicol and Beavan, 2003).

The southern Hikurangi margin has been seismically active in historic times, but almost all significant earthquakes have been on upper plate faults. The largest historical earthquake is the A.D. $1855 M_{\mathrm{w}} 8.2$ Wairarapa earthquake, which ruptured $120 \mathrm{~km}$ of the Wairarapa fault, and an offshore reverse-fault extension (Fig. 1b; Grapes, 1989; Grapes and Downes, 1997). The A.D. 1855 earthquake produced large dextral offsets on the Wairarapa fault (up to $18.7 \mathrm{~m}$; Rodgers and Little, 2006) and widespread coastal vertical motion of the southern North Island coastline and parts of the northeastern South Island, including subsidence of parts of Big Lagoon (Grapes and Downes, 1997; Hayward, Wilson, et al., 2010; Fig. 1). The Wairarapa fault is thought to be listric to the subduction interface (Henrys et al., 2013), and the pattern of crustal deformation caused by the A.D. 1855 Wairarapa earthquake is consistent with the deep portion of the subduction interface ( $\sim 18-30 \mathrm{~km}$ depth), rupturing synchronously with the upper plate fault (Darby and Beanland, 1992; Beavan and Darby, 2005). The A.D. 1855 Wairarapa earthquake generated a tsunami with a maximum runup height of $10 \mathrm{~m}$ in the southern North Island and up to 4-5 m in Cloudy Bay (Fig. 1b; Grapes and Downes, 1997). Of note for this study are historical accounts of the tsunami that overtopped the Wairau Bar (Fig. 2a) and "rose fourteen feet [4.3 m] above high-tide mark...scouring, uprooting, leaving fish on dry land..." (Garin, 1855; (E) for further accounts of the A.D. 1855 tsunami in Cloudy Bay, see the electronic supplement to this article).
In A.D. 1848 an $M_{\mathrm{w}}$ 7.4-7.7 earthquake occurred on the Awatere fault in the northern South Island (Fig. 1b). Ground surface rupture occurred along the Awatere fault and historical documents suggest liquefaction probably occurred in Big Lagoon (Grapes and Downes, 1997). In July and August A.D. 2013, an earthquake doublet of $M_{\mathrm{w}} 6.6$ and 6.5 occurred in southern Cook Strait. These shallow $(<13 \mathrm{~km})$ earthquakes were on an unidentified northeast-southwesttrending upper plate structure (Holden et al., 2013). The earthquakes produced minor landslides and liquefaction but no coastal deformation or tsunami (Van Dissen et al., 2013).

Historical seismicity on the plate interface of the southern Hikurangi margin is restricted to moderate magnitude earthquakes, with the largest being $M_{\mathrm{w}} 6.4-6.5$ in A.D. 1961 and $M_{\mathrm{w}} 5.6$ and 5.5 in A.D. 1990, all offshore, east of Cape Palliser (Doser and Webb, 2003). There are some large earthquakes in the historic catalog (Geonet Earthquake Catalogue, see Data and Resources), such as $M_{\mathrm{w}} 7.5$ and 6.6 in northern Wairarapa in 1863 and 1917, respectively, that do not have known sources and may be interface ruptures, but otherwise there has been no documented seismic rupture of the plate interface beneath land of the southern Hikurangi margin during the instrumental period since $\sim$ A.D. 1917 (Wallace et al., 2009).

\section{Big Lagoon Study Area}

Big Lagoon is located in the southeastern Wairau River valley at the southern end of the Hikurangi margin (Figs. 1 and 2). The lagoon is protected from the open coast by an $8 \mathrm{~km}$ long gravel barrier (Wairau Bar). The paleogeographic history of Big Lagoon through the Holocene is of gradual infilling, shallowing, and decreased connection with the open ocean (Hayward, Wilson, et al., 2010). Approximately 1500 yrs B.P., the embayment switched from a sheltered subtidal bay to a semienclosed lagoon (Hayward, Wilson, et al., 2010), suggesting the Wairau Bar has been similar to its present day configuration for $\sim 1500 \mathrm{yrs}$. The gravel bar varies in width (30-500 $\mathrm{m}$ wide); and, at its narrowest points, storm waves wash over the barrier, carrying lobes of coarse sediment into the lagoon.

Sediment cores from previous studies on the southern and western margins of Big Lagoon show evidence of net tectonic subsidence since the mid-Holocene at rates of $\sim 0.2-1 \mathrm{~mm} / \mathrm{yr}$ (Hayward, Wilson, et al., 2010; Clark, Hayward, et al., 2011; Clark, Van Dissen, et al., 2011). Aside from subsidence attributed to the A.D. 1855 earthquake, no coseismic events were identified in these studies (Hayward, Wilson, et al., 2010; Clark, Hayward, et al., 2011). The amount of subsidence during the A.D. 1855 Wairarapa earthquake was not surveyed but historical observations and estimates have been compiled by Grapes and Downes (1997). Estimates vary from 0.5 to $1.5 \mathrm{~m}$, with observations such as waterlogged farm land, deeper rivers, and increased inland tidal reach. The location of observations is typically vague, such as "lower Wairau Valley," but Budges Island at the northern edge of Big Lagoon is estimated to have subsided $0.5 \mathrm{~m}$, an amount consistent with geological 
(a)

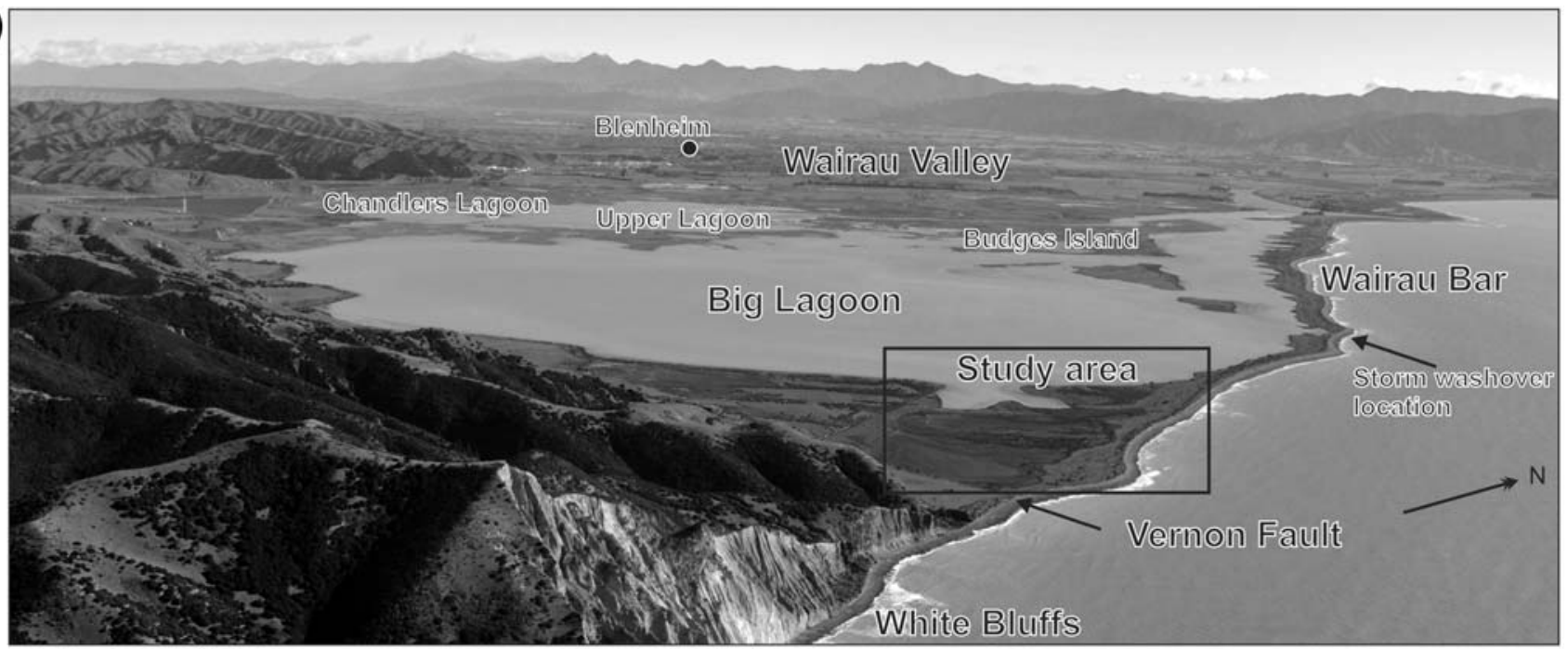

(b)

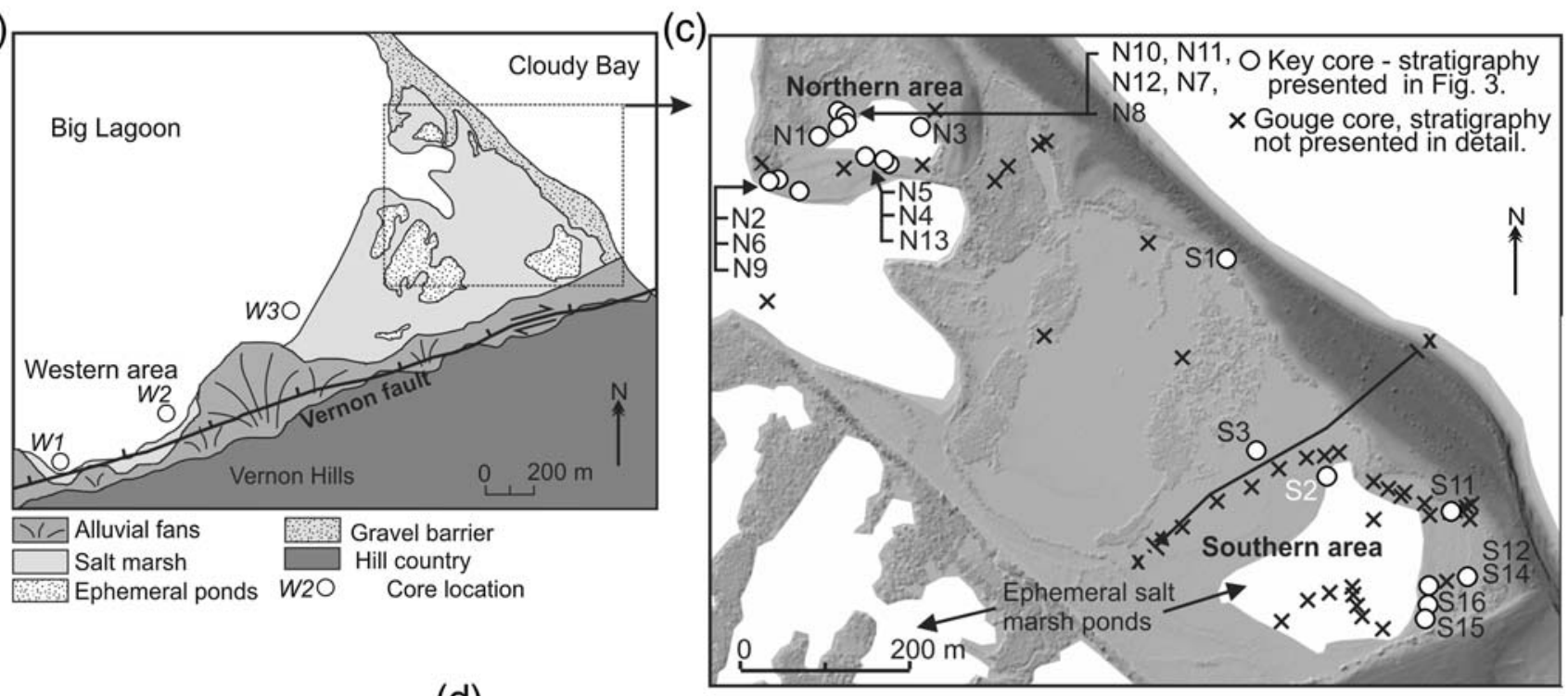

(d)

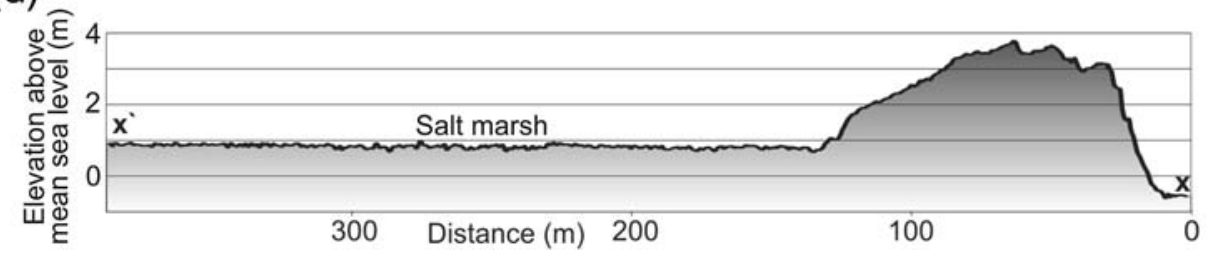

Figure 2. (a) Oblique aerial photo of the lower Wairau Valley showing Big Lagoon, the Wairau Bar, and the salt marsh study area. Photo by Graham Hancox (GNS Science). (b) Geomorphic map of the Big Lagoon salt marsh study area with the western area cores sites shown. (c) Topography of the Big Lagoon salt marsh showing the core locations in the northern and southern areas where detailed stratigraphic studies were carried out. Light Detection and Ranging (LiDAR) image shaded by elevation, see (d) for elevation scale. (d) Topographic profile $\left(x-x^{\prime}\right)$ from the low-tide mark on the open coast, over the Wairau Bar and across the southern area salt marsh. Topographic profile obtained using real-time kinematic Global Navigation Satellite System (RTK-GNSS; see the Methods section for description).

observations of a buried soil by Hayward, Wilson, et al. (2010). The relatively large amount of subsidence in the center of the Wairau Valley is at least partially attributed to soft sediment compaction due to the area being underlain by up to $40 \mathrm{~m}$ of postglacial marine, estuarine, and aeolian deposits of the Dillons Point Formation (Brown, 1981). There are no historical observations of subsidence at our study site in the southeastern corner of Big Lagoon, but Grapes and Downes (1997) note there are no reports that subsidence affected the coastal route around the White Bluffs (near our study site, Fig. 2a), and it would likely have been commented on if there was disruption to this route.

Big Lagoon is bounded to the south by the obliquestrike-slip Vernon fault (Fig. 2), but despite its proximity, 
the Vernon fault has probably not played a role in recent tectonic subsidence of Big Lagoon (Bartholomew et al., 2014). At sites close to Big Lagoon, the Vernon fault has dip-slip rates of $0.04-0.14 \mathrm{~mm} / \mathrm{yr}$ (Bartholomew et al., 2014). The discrepancy between the Vernon fault vertical slip rate and the Big Lagoon subsidence rate $(0.2-0.8 \mathrm{~mm} / \mathrm{yr})$ suggests the Vernon fault is not the primary driver of Big Lagoon subsidence. High-resolution seismic reflection lines showing offsets in recent marine sediments offshore suggest the last rupture of the offshore Vernon fault was $3200 \pm 700$ yrs B.P. (Pondard and Barnes, 2010). Onshore paleoseismic studies of the Vernon fault found evidence for an earthquake $<9000$ yrs B.P. (Clark, Van Dissen, et al., 2011), which is consistent with the offshore data.

This study focuses on the salt marsh in the southeastern corner of Big Lagoon (Fig. 2); it is a small $\left(\sim 0.77 \mathrm{~km}^{2}\right)$ triangular wedge of salt marsh, bounded by the Wairau Bar, the lagoon, and the Vernon fault (covered by alluvial fans). The salt marsh is a mixture of ephemeral ponds, rush-dominated or saltwort-dominated wetlands, and grass-covered gravel bars. Both the lagoon and ponds have varying salinity, depending on the season and degree of freshwater input to the lagoon. Lagoon sediments are dominated by mud and, at some margins of the lagoon, are narrow beaches of sandy gravel with rare shells. The Wairau Bar is cobble-to-pebble dominated from the storm beach to the crest of the bar, with fine pebble to coarse sand on the intertidal beach face.

\section{Methods}

\section{Core Collection and Surveying}

Sediment cores from the Big Lagoon salt marsh were obtained using a gouge auger or piston corer, and all were visually described, photographed, and sampled in the field. A selected number of cores were retained and described in greater detail in the laboratory. All core sites were surveyed using a handheld Global Positioning System (GPS). Topographic features such as the Wairau Bar crest and the locations of some cores were surveyed using a Leica real-time kinematic Global Navigation Satellite System (RTK-GNSS), which has higher elevation accuracy than the handheld GPS $(<5 \mathrm{~cm}$ uncertainty ranges). As there are no nearby geodetic benchmarks, the elevation relative to mean sea level (MSL) was estimated using natural tidal features, such as water level at low tide and high tide debris lines along the open coast. We estimate the uncertainty of core elevations relative to MSL to be $\pm 0.5 \mathrm{~m}$. Not all core tops were surveyed with the high precision GNSS because most cores came from a relatively flat surface (Fig. 2d), and elevation differences were minor.

\section{Micropaleontology}

Samples of approximately $10 \mathrm{~cm}^{3}$ of sediment were washed over a $>63 \mu \mathrm{m}$ sieve, and the dried sand was examined for foraminifera; 132 samples from 16 cores (N1-4, N6, N9, N12, N13, W2, W2, S1, S4, S8, S11, S13, and S15) were examined, along with three modern samples from the lowtide and intertidal beach face and a storm washover deposit (modern samples from the Big Lagoon salt marshes were examined by Hayward, Wilson, et al., 2010). Some samples with low foraminifera density were floated using sodium polytungstate to concentrate the foraminifera tests. Where possible, $\geq 100$ tests were identified (with reference to Hayward et al., 1997; Hayward, Grenfell, Reid, et al., 1999).

The tidal elevation at which each fossil foraminiferal fauna accumulated, was estimated using the modern analog technique (MAT), which is the preferred technique for estimating past relative sea levels using benthic foraminifera in New Zealand (e.g., Hayward et al., 2004) because it is based on many more modern faunas than comparable international studies and requires fewer statistical assumptions than transfer functions. The MAT compares the relative abundance of benthic foraminiferal species in fossil faunas (we used samples with $>30$ specimens) with a modern dataset of foraminiferal samples. Estimates of tidal elevation or water depth were computed for each fossil fauna as the mean elevation and range of the five modern faunas with the most similar faunal composition (using a squared chord dissimilarity coefficient). The modern dataset comprised 639 foraminiferal samples from New Zealand sheltered harbors and estuaries, including 27 samples from modern salt marsh transects in Big Lagoon (E) see Table S6). The tidal range around New Zealand varies from $\sim 1$ to $5 \mathrm{~m}$, therefore the tidal elevations of the modern samples are converted to a ratio of the extreme tidal ranges at the sample sites. The derived MAT elevation estimate is obtained as a tidal ratio, which is then converted to the presentday extreme tidal range $(1.4 \mathrm{~m})$ of Big Lagoon (E) for the conversion of the modern dataset tidal ratio to the Big Lagoon tidal range, see Table S6). Confidence limits quoted in this study for the MAT elevation estimates are the range of elevations of the five nearest modern analogs. Uncertainties on the paleoelevation estimates are typically low $( \pm 0.1 \mathrm{~m})$ for fossil salt marsh faunas (above mean high water tide levels) because the elevation range of the modern fauna is narrow $(<0.2 \mathrm{~m})$. Conversely, uncertainties increase with lower elevations as the elevation range of the modern faunas expands; for example, the elevation range of intertidal foraminifera assemblages can be $>1 \mathrm{~m}$, thus the uncertainties similarly increase.

Diatom samples were processed using standard methodology (e.g., Cochran et al., 2006), and species were identified with reference to standard floras (e.g., Round et al., 1990; Krammer and Lange-Bertalot, 1991, 1999a,b, 2000; Hartley, 1996; Witkowski et al., 2000). At least 150 valves were counted in each of the 11 samples investigated. Over 70 species were identified, and these were grouped according to their salinity and habitat preferences, as defined by Vos and de Wolf (1993) and van Dam et al. (1994) ((E) see Tables S4 and S5).

\section{Grain-Size Analysis}

Grain-size samples were dried and split over a $63 \mu \mathrm{m}$ mesh. The $>63 \mu \mathrm{m}$ fraction (sand size and greater) was 
sieved over $1-\Phi$ interval sieves from 4 to $0 \Phi$. Each fraction was weighed. The $<63 \mu \mathrm{m}$ fraction was put through a Beckman-Coulter LS 13-320 laser diffraction particle size analyzer fitted with an aqueous liquid module (ALM) using filtered plain water. The samples were added to the ALM as aliquots of dry material and ultrasonically dispersed prior to each run. Multiple runs of each sample were made to check for reproducibility, and the final data are an average of the most similar three (or more) runs. The data from the laser sizer are a volume percentage that is approximately equivalent to weight percent. The $<63 \mu \mathrm{m}$ fraction was binned at $1-\Phi$ intervals, and results were merged with the sieving data.

\section{Age Control}

Age control was obtained from radiocarbon dates on plant material, organic sediment, or shell. In most cases, peat or organic-rich silt was targeted for dating, and from the silt we attempted to select delicate, short-lived plant fragments so as to obtain material that had not been reworked prior to deposition. We tried to avoid rootlets or plant fragments that were oriented vertically up the core so as to minimize the risk of young material contaminating the sample. Of the 28 samples, we were able to select discrete plant fragments for dating in 12 samples. For 11 samples, we had to use bulk sediment because plant fragments could not be separated from the sediment. For three samples, we dated wood fragments; this was a less desirable target material due to the risk the wood had been reworked prior to deposition. One dated sample was an estuarine shell, and duplicate dates were obtained from the shell due to a potential laboratory error. Radiocarbon age calibration was undertaken using the program OxCal v. 4.2 (Bronk Ramsey, 2009) with the ShCal13 atmospheric curve for terrestrial samples (Hogg et al., 2013); for shell samples, we used the Marine13 curve (Reimer et al., 2013) with a Delta-R of $-30 \pm 13$. Calibrated ages are quoted in calibrated years before present (cal B.P.) at the 95\% uncertainty range. Earthquake age modeling was undertaken using Bayesian statistical modeling in OxCal; we followed the methodology for paleoseismic studies outlined in Lienkaemper and Bronk Ramsey (2009). The chronologic model consists of a sequence of phases and radiocarbon ages with the location of the paleoearthquakes inserted at the appropriate stratigraphic position. Phases are groups of radiocarbon ages obtained from correlated stratigraphic units; within the phase there are no assumptions of chronologic ordering. Radiocarbon ages are used outside of phases when the stratigraphic position relative to one another is known (i.e., usually because they are from the same core) and an assumption of the chronologic ordering can be made. Using the "Date" command, OxCal incorporates the radiocarbon ages bracketing the paleoearthquake stratigraphic horizons to constrain the earthquake age. The earthquake age is given as a probability density function, and we report the age at the $95 \%$ uncertainty range.

\section{Identification of Paleoearthquakes and Quantifying} Displacement

Five criteria for assessing regional coastal subsidence due to earthquakes were developed from studies along the Cascadia subduction zone by Nelson et al. (1996). We use these criteria for evaluating evidence of paleoearthquakes at Big Lagoon. The criteria are (1) the suddenness of submergence, (2) the amount of submergence, (3) the lateral extent of submerged tidal-wetland soils, (4) coincidence of submergence with tsunami deposits, and (5) degree of synchroneity at widely spaced sites.

Our primary method of quantifying the earthquake displacement (criteria 2, above) is through the use of foraminiferal assemblages, specifically using the MAT. Salt marsh foraminiferal species are zoned with respect to tidal elevation, and their relative abundances can be used to quantify past tidal elevations (Hayward, Grenfell, and Scott, 1999; Hayward et al., 2004). Diatom samples were studied in three cores; however, diatom distributions tend to be influenced more by salinity than tidal elevation, and in Big Lagoon salinity is not consistently related to tidal elevation. Therefore, foraminifera are a preferable tool for estimating past tidal elevations in Big Lagoon.

\section{Results}

Forty-eight cores (0.5-2.2 m deep) were taken from the Big Lagoon salt marsh (Figs. 2c and 3). The cores are concentrated around the northern ephemeral pond (henceforth called the northern area) and around the southeastern corner of the salt marsh (southern area, Fig. 2c). The density of cores in these two areas reflects the variability and significance of the stratigraphy. There are also some cores that were taken in a small embayment to the west (western area) and some scattered cores in between (Fig. 2b). We present the stratigraphy of 23 cores in Figure 3; (E) the detailed descriptions of these same cores is shown in Figure S3. Many cores were collected in a gouge auger to assist with lithofacies correlation or to record the depths of significant contacts; these cores were not described in detail, and their simplified stratigraphy is presented in Figure S2. In the following section, we describe the lithofacies in the northern and southern areas, along with the micropaleontology. We then present an integrated paleoenvironmental interpretation for the salt marsh area and the age control. To assist interpretation of the foraminifera assemblages, Figure 4 shows the most common foraminiferal species associations in the core samples, along with the environmental habitats of each association (Hayward, Grenfell, Reid, et al., 1999; Hayward, Grenfell, and Scott, 1999; Hayward et al., 2004). Figure 5 shows summary graphs of the foraminifera distributions and abundances through six representative cores, along with the diatom distributions through two of these cores. 


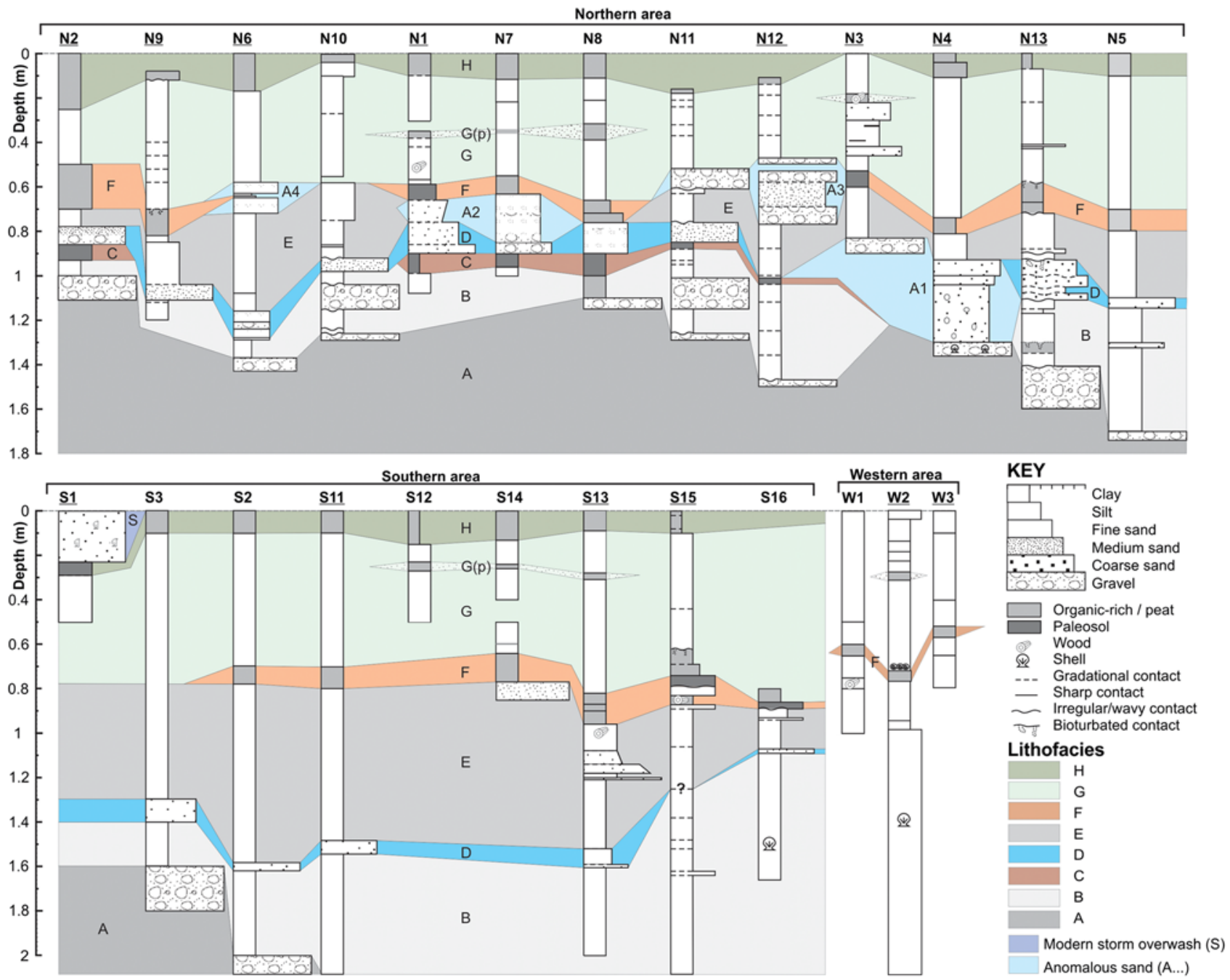

Figure 3. Stratigraphy and lithofacies correlations of the Big Lagoon salt marsh cores. Underlined core names denote those from which micropaleontology samples have been studied. See Figure 2 for core locations. (E) Detailed core logs and sediment descriptions for all cores are contained in Figure S3 in the electronic supplement to this article. The color version of this figure is available only in the electronic edition.

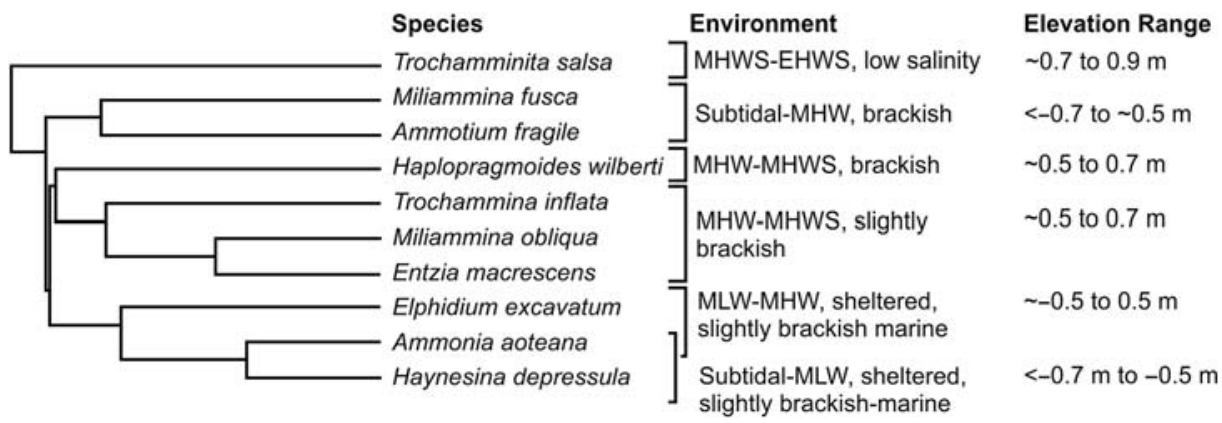

Figure 4. Pearson coefficient cluster dendrogram of the common foraminifera species in the Big Lagoon salt marsh core samples. This figure illustrates how the common foraminifera associations of the Big Lagoon salt marsh core samples relate to environmental conditions that typically vary according to elevation and salinity. The approximate elevation ranges (relative to mean sea level [MSL]) of the common foraminifera associations is shown in the right column, but more precise estimates of elevation are obtained using the modern analog technique (see the Methods section). All samples with fewer than 20 specimens were removed from the analysis, as were samples from lithofacies $\mathrm{D}$, due to the high proportion of transported species in this lithofacies. The relative abundance of foraminifera in 68 samples was used in this cluster analysis. The environmental affinities of each assemblage are interpreted with reference to Hayward and Hollis (1994), Hayward, Grenfell, Reid, et al. (1999), and Hayward et al. (2004). EHWS, extreme high water spring tide level; MHWS, mean high water spring tide level; MHW, mean high water tide level; MLW, mean low water tide level. 


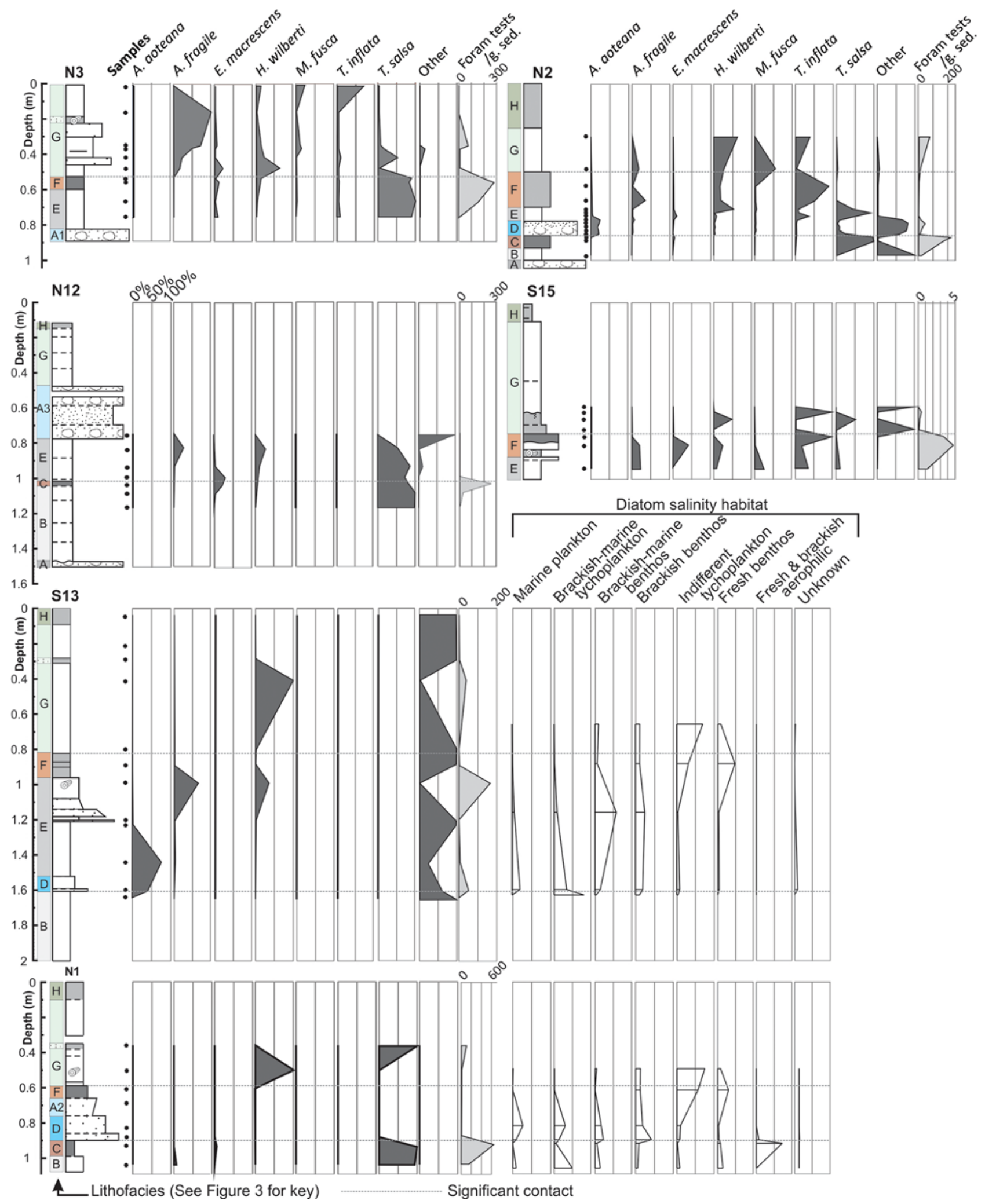

Figure 5. Microfossil abundances in six representative Big Lagoon salt marsh cores. Relative abundances of the seven most common foraminifera species (plus the abundance of all other species) are shown (foraminiferal generic names are given in full in Fig. 4). The key contacts in relation to paleoearthquake occurrence are shown by a dashed gray line. All foraminifera species abundance graphs are at the same scale of $0 \%-100 \%$. The scale for the foraminifera concentration (foraminifera tests per gram of sediment) varies. For cores S13 and N1, we also show the diatom-salinity habitat categories plotted against depth. (E) Full diatom species lists are in Table S4, and a summary of the diatom paleoenvironmental information is in Table S5. The complete foraminifera census data for all the cores shown here plus cores N1, N4, N6, N9, N13, S1, S4, S8, S11, W3, W1, and BL10/7 are in Table S2. The color version of this figure is available only in the electronic edition. 
Northern and Southern Areas: Lithofacies

Descriptions and Micropaleontology

Lithofacies $A$. The basal unit in most of the cores is a rounded fine gravel (clasts $<20 \mathrm{~mm}$ diameter) in a coarse sand matrix. Core N4 is the only one to have shell grit within the basal gravel. A foraminiferal sample in core N6 has a low abundance assemblage of Haplophragmoides wilberti, Trochamminita salsa, and Trochammina inflata.

Lithofacies B. Overlying the basal gravel is massive, medium gray clay or silt; this has rare millimeter-scale plant fragments in some cores. Seven of the eight foraminiferal samples from lithofacies B are dominated by $T$. salsa, with low numbers of Ammonia aoteana and $\mathrm{H}$. wilberti, and one sample from core N9 is dominated by $H$. wilberti. A brackish-wetland diatom assemblage was observed in core N1 (Fig. 5). Five samples from the upper $10 \mathrm{~cm}$ of lithofacies B in core N9 were analyzed for grain size (Fig. 6); all are dominated by silt with a high proportion of clay and little sand. In core S16, from the southern area, lithofacies B contains a single Paphies australis (pipi) valve at $1.5 \mathrm{~m}$ depth.

Lithofacies $C$. In many of the northern area cores, lithofacies $B$ is overlain by a thin $(<10 \mathrm{~cm})$ but well-developed dark brown paleosol called lithofacies C. The paleosol typically has a gradational lower contact, in places showing root channels reaching down into lithofacies B (e.g. N12, Fig. 7). It has a sharp upper contact, crumbly soil structure, and is rich in humified organic matter. A diatom sample from core N1 is dominated by flora typical of a brackish soil environment (Fig. 5). Foraminifera samples from cores N1, N2, and $\mathrm{N} 12$ are dominated by $T$. salsa; the sample from N12 contains a subsidiary component (19\%) of Entzia macrescens. In some cores of the northern area lithofacies $\mathrm{C}$ is not present (e.g. N5, N6, N9, N10,) and is absent in the southern area (Fig. 3).

Lithofacies D. In most cores of the northern area, lithofacies $\mathrm{C}$ (or lithofacies $\mathrm{B}$ where $\mathrm{C}$ is absent) is overlain by a medium to coarse gray sand; the sand is also present in most southern area cores that reached depths of $>1 \mathrm{~m}$ and are within $\sim 360 \mathrm{~m}$ of the gravel bar (Fig. 3). The sand typically has a sharp base, and a gradational, or sharp and irregular upper contact (cores S16, N9, and N11 in Fig. 7). Lithofacies $\mathrm{D}$ is quite variable in lithology, in many cores it contains rounded pebbles up to $10 \mathrm{~mm}$ diameter scattered through the sand, it often has millimeter-scale shell fragments and, in rare cases, has millimeter-scale plant fragments throughout and barnacle plates at the base. Lithofacies D is up to $10 \mathrm{~cm}$ thick, but in the southern area it thins landward. For example, cores S3-S6 were collected along a seaward-to-landward transect to trace lithofacies $\mathrm{D}$, and we found it thins from $10 \mathrm{~cm}$ in $\mathrm{S} 3$ to $4 \mathrm{~cm}$, to $1 \mathrm{~cm}$, and then is absent in $\mathrm{S} 6$ at $370 \mathrm{~m}$ inland (ㅌ) see Fig. S2).

The micropaleontology of lithofacies $\mathrm{D}$ is highly diverse, as shown by both foraminifera and diatom assemblages. The unusual foraminifera assemblage is best demonstrated by core $\mathrm{N} 2$ in which five samples were examined
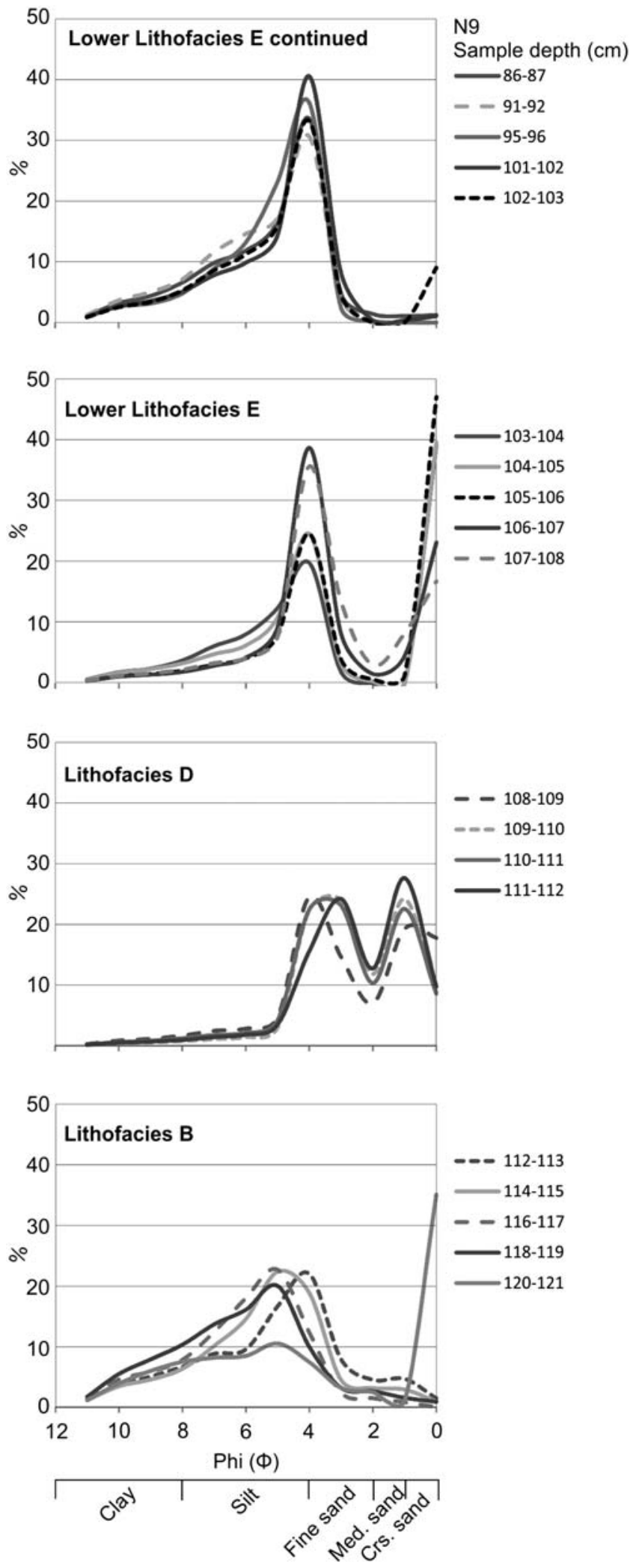

Figure 6. Grain size distribution, by percentage weight, in 19 samples from below, through, and above lithofacies D in core N9 (see core photo in Fig. 7). This shows that lithofacies B, below lithofacies D, is silt dominated. Lithofacies D has a double fine- and coarse-sand peak, and lithofacies E becomes progressively finer grained and dominated by silt upwards. 


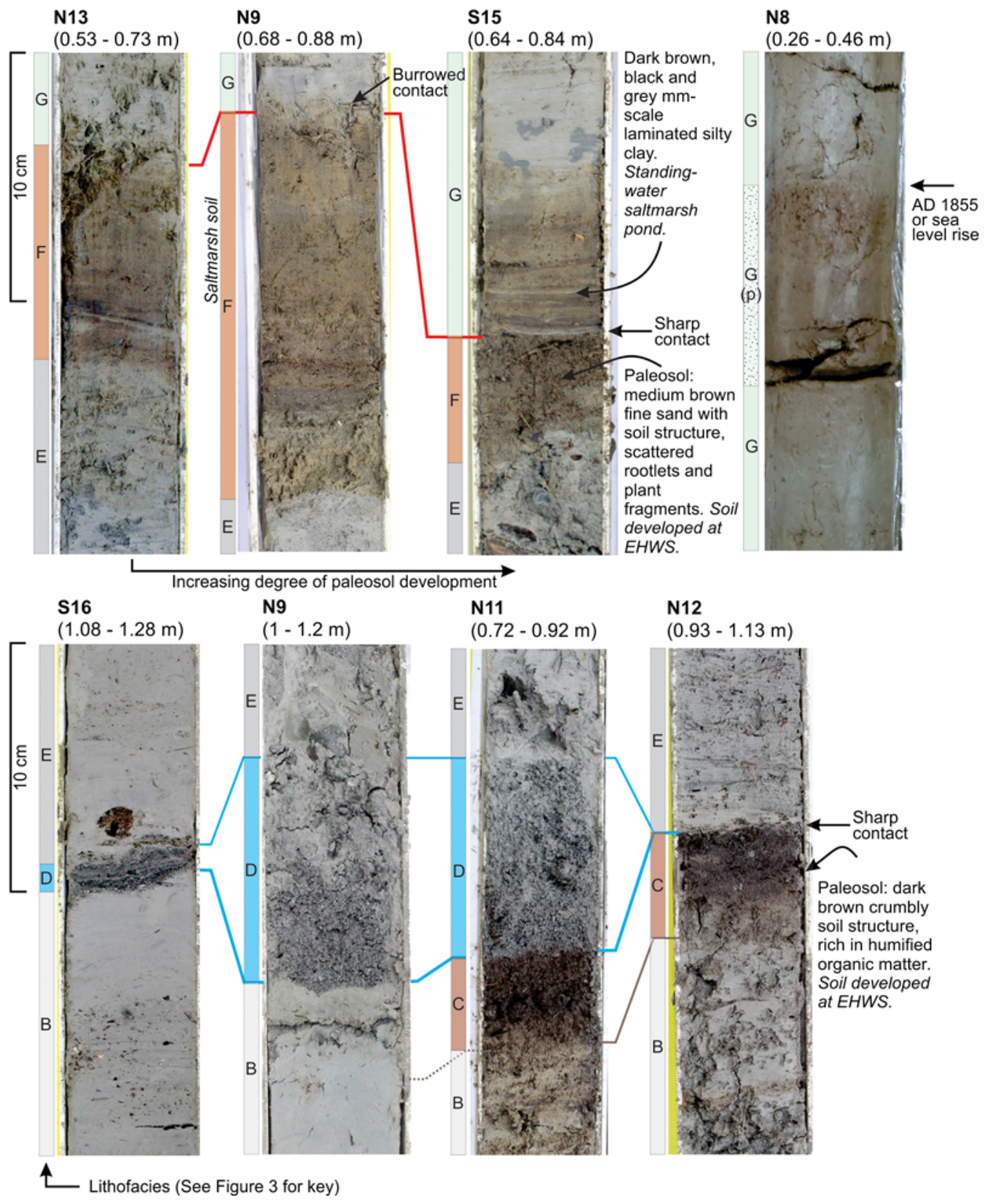

Figure 7. Representative photos of the important stratigraphic contacts in the Big Lagoon salt marsh cores. The three upper left images show the varying expressions of the lithofacies E-F-G contact, and the upper right image shows lithofacies G(p). Lower images show the varying expressions of the lithofacies B-C-D contacts. The color version of this figure is available only in the electronic edition.

(Fig. 8). They comprise $\sim 50 \%$ species from a subtidal open marine environment, $\sim 20 \%$ species from semisheltered, near-normal salinity subtidal environments, $\sim 20 \%$ intertidal species from slightly brackish lagoons or inlets, and $\sim 10 \%$ species from brackish salt marshes (Fig. 8; (E) Table S3). Lithofacies D in core N1 contains a mixture of diatoms from different habitats (mainly brackish-marine benthics, but also marine plankton and fresh-brackish soil diatoms; Fig. 5). Lithofacies D microfossil samples differ from all others in this study in containing acorn barnacle (Austrominius modestus) plates, sponge spicules, ostracods, and planktic foraminifera. Four samples through lithofacies D in core N9 were analyzed for grain size (Fig. 6); they have a bimodal peak of fine and coarse sand.

Lithofacies E. Massive gray silt or clay overlies lithofacies D throughout most of the salt marsh (Fig. 3). The clay is similar in appearance to lithofacies B; in some cores it is slightly mottled and contains millimeter-scale plant fragments and scattered rounded pebbles. In the southern area, lithofacies E shows iron oxidation toward the top and also centimeterscale pieces of wood just below the upper contact. Foraminiferal samples from cores N2-4 and N12 in the northern area are dominated by $T$. salsa with less common Ammotium fragile, $H$. wilberti, E. macrescens, and T. inflata, except in core N6 in 


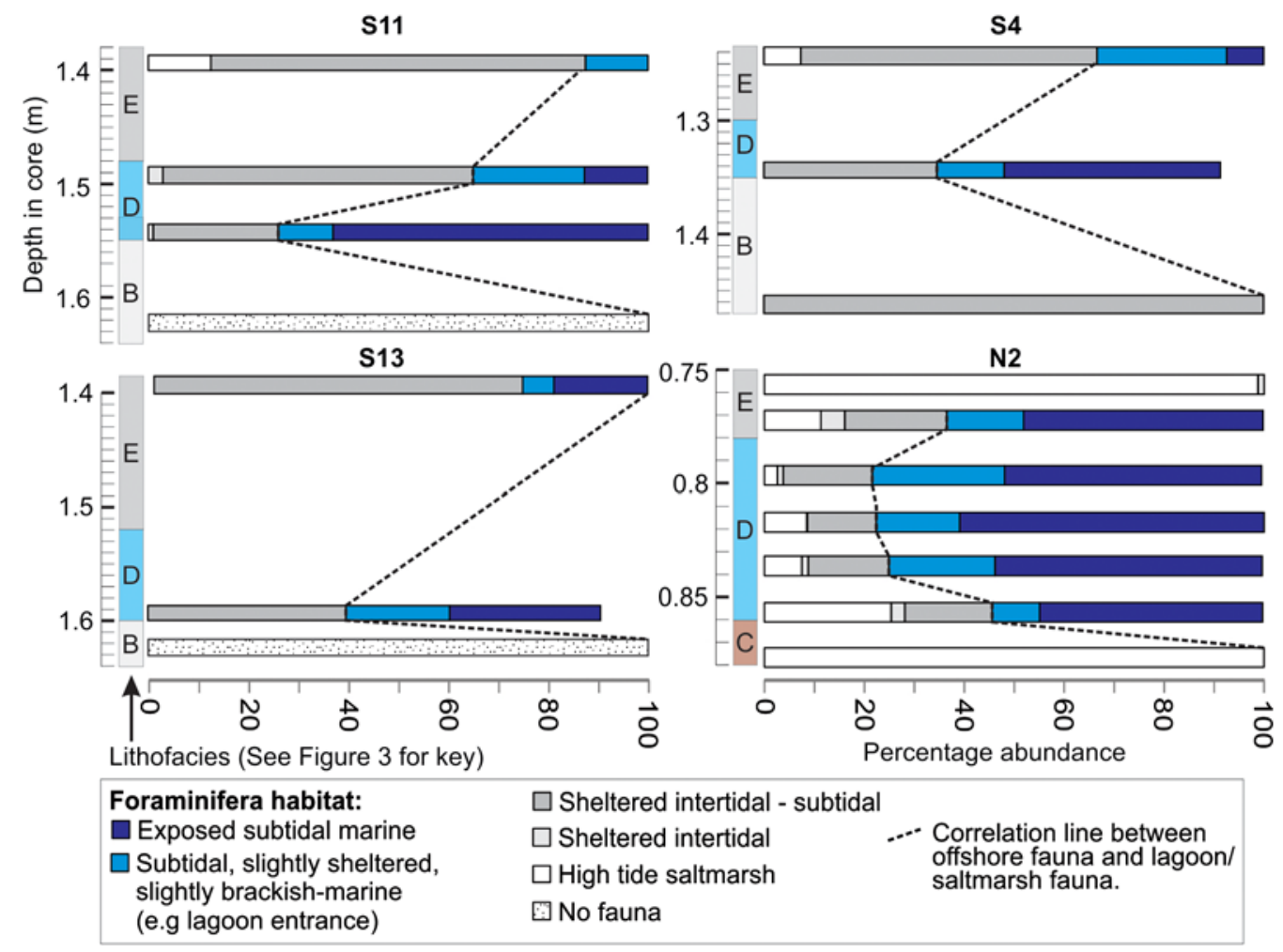

Figure 8. The foraminiferal composition of samples from below, within, and above lithofacies $\mathrm{D}$ in four representative cores. This shows how the foraminiferal composition of lithofacies D is significantly different from the underlying lithofacies. The lower part of lithofacies D typically has a high proportion of subtidal open marine foraminifera, whereas the proportion of sheltered intertidal to salt marsh foraminifera increases up through lithofacies D. (E) For the classification of foraminifera species into the foraminifera habitats listed in this graph, see Table S3. The color version of this figure is available only in the electronic edition.

which lithofacies E is dominated by $T$. inflata and $H$. wilberti with subsidiary Miliammina fusca. Most foraminiferal samples within lithofacies $\mathrm{E}$ in the southern area are devoid of formaminifera or contain such low abundances that environmental interpretations are unreliable (Fig. 5). Two samples with sufficient foraminiferal abundances are from lithofacies $\mathrm{E}$ in core $\mathrm{S} 13$; a basal sample is dominated by A. aoteana, and a sample from the top is dominated by $A$. fragile and $H$. wilberti (Fig. 5). The absence of fauna in all other samples is probably due to weathering, signaled by the iron oxidation mottling seen in many cores. Ten samples from the basal $0.2 \mathrm{~m}$ of lithofacies $\mathrm{E}$ in core $\mathrm{N} 9$ were analyzed for grain size (Fig. 6). The samples are fine sand with an increasing proportion of silt and clay toward the top.

Lithofacies F. Organic clay overlies lithofacies E in most of the northern area and throughout the southern area. The clay is variable in appearance, ranging from light brown clay to silty fibrous peat, showing signs of soil development, to humified soil (Fig. 7). It is commonly partially or fully laminated at a millimeter scale and usually has horizontally lying millimeter-scale plant (rush and grass) fragments throughout and some rootlets. Where a well-developed soil occurs in cores S15 and S16, it is a medium brown, organic-rich, fine sand with soil structure, rootlets, grasslike plant fragments, and millimeter-scale charcoal pieces (Fig. 7). The basal con- tact of lithofacies $\mathrm{F}$ is sharp in some cores (e.g., N9, N13; Fig. 7) and gradational in others (e.g., N1 and N4). The upper contact is typically either sharp or irregular with signs of bioturbation (e.g., in cores N9 and N13; Fig. 7). Lithofacies F is usually $\sim 10 \mathrm{~cm}$ thick but can be up to $20 \mathrm{~cm}$ thick.

In lithofacies $\mathrm{F}$, foraminifera are absent or in very low abundance in most cores of the northern area, with the exception of core N3, in which samples are dominated by T. salsa, with subsidiary $H$. wilberti or E. macrescens (Fig. 5). Of two foraminiferal samples from the well-developed soil in core S15, one contained a low abundance of $T$. inflata and the other was dominated by E. macrescens with subsidiary A. fragile and $\mathrm{H}$. wilberti (Fig. 5). Elsewhere in the southern area (S13 and S11), lithofacies F contained no foraminifera. Diatom samples from within lithofacies F in core S13 contained flora typical of a fresh-brackish wetland (Fig. 5).

Lithofacies $G$. Gray to light brown silty clay overlies lithofacies F (Fig. 3). This clay is typically gray toward the base and becomes gray-brown to brown toward the top. It is frequently mottled and contains millimeter-scale plant fragments and many rootlets. In many cores, there are dark brown laminations composed of horizontally lying stringy plant fragments, resembling the algal mat layers that surround the edges of the lagoon in the present day. In three cores of the northern area and three cores in the southern 
area, there is a layer of dark brown, organic-rich clay at $\sim 30 \mathrm{~cm}$ depth; this may be an incipient paleosol, that we call lithofacies $\mathrm{G}(\mathrm{p})$.

Foraminiferal assemblages in lithofacies $\mathrm{G}$ from core $\mathrm{N} 3$ are dominated by $A$. fragile with subsidiary $H$. wilberti and $T$. salsa or are dominated by $H$. wilberti or $T$. salsa (Fig. 5). In cores N2 and N4, foraminiferal assemblages from lithofacies $\mathrm{G}$ are dominated by $H$. wilberti, $M$. fusca, or T. inflata; M. fusca dominated assemblages occur at the base of lithofacies G. Similar assemblages were recorded in core S13, but most other lithofacies $\mathrm{G}$ samples from the southern area contained no, or very low, abundances of foraminifera (Fig. 5). A diatom sample from the base of lithofacies $G$ in core N1 contained a relict assemblage of brackish salt marsh diatoms but was dominated by Staurosirella pinnata (basionym Fragilaria pinnata). A foraminiferal sample from lithofacies $\mathrm{G}(\mathrm{p})$ in the northern area (core N1) is entirely $T$. salsa. A sample from lithofacies $\mathrm{G}(\mathrm{p})$ in core $\mathrm{S} 12$ (not shown in Fig. 5) had a diatom flora characteristic of brackish soil.

Lithofacies $H$. Capping the sequence throughout the salt marsh is the modern salt marsh soil (Fig. 3), typically a medium brown peaty soil, with dense plant roots. It is present in all cores except N3, which was collected from the ephemeral salt pond. One foraminiferal sample from lithofacies $\mathrm{H}$ (at the top of core N4) is dominated by $H$. wilberti.

\section{Additional Cores}

Cores were collected from locations outside of the northern and southern areas to provide a wider paleogeographic context and to trace the spatial extent of key stratigraphic horizons (Fig. 2b). In the western area (Fig. 2b), cores reached up to $3.5 \mathrm{~m}$ depth and did not sample gravel (Fig. 3). We have not correlated lithofacies A-E and G-H to the western area due to a lack of age control in the western area and because the foraminifera and molluscs of the western area are typically from intertidal depositional environments and therefore have no paleoenvironmental equivalent in the northern and southern areas. One lithofacies that can be correlated to the western area cores is lithofacies F (Fig. 3); this is lithologically and stratigraphically similar to lithofacies $\mathrm{F}$ in the northern and southern areas (a dark brown laminated clay), and a radiocarbon date confirms it is of similar age.

Several cores were collected across the salt marsh in between the northern and southern areas (Fig. 2c). These were generally shallow ( $<1 \mathrm{~m}$ depth) and contained massive silt and sand with few stratigraphic markers that could be correlated to cores elsewhere. We infer this middle area was formerly a more current-swept embayment that developed less of the fine-grained salt marsh stratigraphy seen elsewhere. The area also appears to be underlain by several shallow $(<1 \mathrm{~m})$ gravel bars, which are perhaps former beach lines marking lagoon retreat.

Core S1 was collected to sample a modern storm washover deposit (Figs. 2c and 3). The storm washover deposit is well-sorted coarse gray sand with shell grit; it contains no fine sediment (< sand-sized) material and no foraminifera. Samples were also collected from the modern low-tide beach face and midtide beach face. These are also well-sorted coarse sand with no foraminifera.

\section{Paleoenvironmental Interpretation}

The variable stratigraphy and microfossil assemblages of the cores collected from Big Lagoon suggest a complex paleoenvironmental history with paleoelevations ranging from intertidal to highest salt marsh, and the observed stratigraphic sequence of environments is not that expected from a simple lagoon infilling sequence. Lithofacies $\mathrm{A}-\mathrm{H}$ are correlative across the study area with only minor stratigraphic variations within and between each area. Here, we describe the general paleoenvironmental history from oldest to youngest with reference to lithofacies $\mathrm{A}-\mathrm{H}$, and then we address the anomalies and exceptions.

Lithofacies A, a coarse sandy gravel, probably represents a former beach face on the leeward side of the Wairau Bar. In the modern lagoon, gravels occur in pockets around the edge of the lagoon and on the bar. The shell grit present in one core indicates a marine depositional environment. The depth to the top of the gravel is relatively variable $(1.1-2 \mathrm{~m}$ range), suggesting a degree of surface topography consistent with a beach and gravel bar environment. In the southern area, the gravel noticeably slopes upward toward the modern bar, suggesting it is contiguous with it.

Foraminiferal assemblages, dominated by $T$. salsa associations, in the massive gray clay (lithofacies B) suggest a low salinity, high-tidal (mean high water springs [MHWS] to extreme high water springs [EHWS] tide level) salt marsh environment in the northern area. The southern area has no fauna, but the fine grain size and absence of bedding implies a quiet backwater environment; the $P$. autralis valve in core $\mathrm{S} 16$ is consistent with a sheltered intertidal environments. A gravel bar had probably formed across the eastern corner of Big Lagoon by this time, and this created a sheltered salt marsh environment in the northern and southern areas, protected by barriers to the northeast and northwest and receiving high freshwater input.

The degree of soil development in lithofacies $\mathrm{C}$ suggests a high salt marsh to near-terrestrial environment, probably much like the saltwort- and rush-covered high marsh of the present day. Foraminifera and diatoms within lithofacies $\mathrm{C}$ are consistent with an EHWS to brackish soil environment; for example, E. macrescens (up to $19 \%$ in a lithofacies C sample) is a highest tidal level indicator that typically lives at higher salinity vegetated sites. Lithofacies $\mathrm{C}$ is not present in the southern and western areas, suggesting the extent of high marsh environment was limited to a small patch in the northern area.

Lithofacies D, a medium-to-coarse sand, has such a highly diverse microfossil content that it cannot have formed in situ. The sand was undoubtedly sourced from multiple depositional environments and emplaced over the salt marsh by an atypical mechanism. The foraminiferal assemblages contain 
high proportions (up to $70 \%$, typically around $50 \%$ ) of species that inhabit subtidal marine environments on exposed coasts (Fig. 8). This type of environment is consistent with the inner shelf ( $>5 \mathrm{~m}$ depth) of Cloudy Bay. Lithofacies D also contains lesser but still substantial proportions $(30-40 \%)$, of foraminifera from sheltered intertidal to subtidal environments of normal (open ocean salinity) to slightly brackish salinity, an environment consistent with the main water body of Big Lagoon (Fig. 8). The diatom assemblages contain species from a range of habitats, and the barnacle plates, sponge spicules, ostracods, and planktic foraminifera were all derived from environments outside of the salt marsh The microfossil mixture of lithofacies D implies the sand was sourced both landward and seaward of its current location. Therefore, lithofacies D consists of allochthonous transported sediment, and we will further interpret the transport mechanism later.

Lithofacies E, a massive gray silt or clay, has foraminiferal assemblages of a low-salinity mean high water (MHW)MHWS salt marsh in the northern area. In the southern area, the rare lithofacies $\mathrm{E}$ foraminiferal samples suggest the area infilled from a sheltered intertidal environment to a more enclosed salt marsh at around MHW. By the end of lithofacies E deposition, the southern area had a similar environment to the northern area.

Lithofacies F, an organic-rich clay, has microfossil assemblages consistently indicative of an MHW-EHWS salt marsh. Lithofacies $\mathrm{F}$ is one of the most widespread and distinctive lithofacies, being present at a depth around $0.6-0.8 \mathrm{~m}$ in almost all cores. It is typically laminated with plant fragments throughout, but in the southern area there is a small region where lithofacies F shows well-developed soil structure (Fig. 7); this is consistent with the dominance of $E$. macrescens in core S15, which indicates vegetation nearby or at the site. The gradational lower contact suggests gradual infilling of a salt marsh up to the level of lithofacies $F$, whereas the sharp and often bioturbated upper contact suggests a sudden paleoenvironmental transition at the top.

Lithofacies G, a gray silty clay, is also present in all study areas, and generally the paleoenvironmental indicators within this sediment point to a salt marsh environment, around MHW-MHWS with variable or fluctuating salinity; the southern area in particular may have had high freshwater input. Lithofacies $\mathrm{G}$ has significantly less organic matter than the underlying lithofacies $\mathrm{F}$, a change that is consistent with deposition at a slightly lower tidal elevation (Fig. 7). At the base of lithofacies $\mathrm{G}$ in core $\mathrm{N} 1$ is a diatom sample dominated by Fragilaria taxa, which are known for their ability to colonize new environments and tolerate fluctuating conditions (Denys, 1988). Samples of lithofacies G frequently lack or have few foraminifera, probably reflecting increased oxidative weathering of the sediment; it is close to the ground surface and probably dried out in periods of prolonged drought. Within lithofacies G, eight cores contain the incipient paleosol called lithofacies G(p). Foraminifera and diatom samples from lithofacies $\mathrm{G}(\mathrm{p})$ confirm a low salinity, brackish soil paleoenvironment, consistent with the higher propor- tion of organic matter in this lithofacies. Lithofacies $G(p)$ has a patchy occurrence but is present in all areas (Fig. 3), so the mechanisms that saw the development and then cessation of this lithofacies were widespread, rather than isolated to a particular pond or area of salt marsh.

There are some anomalous sedimentary layers in the cores that are inconsistent with the general sequence of paleoenvironmental evolution described above. These anomalous sediments occur entirely in the northern area cores (numbered A1-A4 in Fig. 3) and probably reflect a slightly more dynamic environment at this location (compared to the southern area). Each of the anomalous layers is characterized by a coarser grain size than is typical for its stratigraphic position; for example, anomalous layers A 3 and A4 are $10-30 \mathrm{~cm}$ thick packages of gravel and coarse sand at a stratigraphic position where lithofacies $\mathrm{E}$ and $\mathrm{F}$ are expected. Anomalous layers A1 and A2 are medium to fine sand layers in a stratigraphic position where lithofacies B and E, respectively, are expected. Foraminifera samples from the anomalous layers in core $\mathrm{N} 4$ show an $H$. wilberti- and A. fragile-dominated assemblage, consistent with a high tidal depositional elevation, although both samples have subsidiary Paratrochammina bartrami and Portatrochammina sorosa, which are subtidal species. Anomalous layer A4 contains $H$. wilberti- and $T$. inflata-dominated assemblages typical of MHW-MHWS environments. Anomalous layers A2 and A3 contain no fauna.

We suggest the anomalous layers represent the lagoon shoreline that migrated over the salt marsh at varying times and at various locations. The modern lagoon shoreline adjacent to the northern area salt marsh is a mixture of sand and gravel, similar to the anomalous layers. The similarity of the faunal assemblages with surrounding sediment (i.e., mostly MHWelevation assemblages) suggests the anomalous deposits do not represent a significant change in elevation. Given the small size of the northern salt marsh and its position on a promontory jutting into the lagoon (Fig. 2), it is feasible that the lagoon shoreline has migrated over that salt marsh at different times.

\section{Age Control}

Twenty-eight radiocarbon ages have been obtained from the Big Lagoon salt marsh cores (Table 1, Fig. 9). These support our lithofacies correlations and place constraints on the timing of deposition of lithofacies of interest. However, there are a relatively high number of samples that returned a modern radiocarbon age (6 of 28), several instances of radiocarbon ages being anomalously young for their stratigraphic position, and one instance of an anomalously old radiocarbon age. A variety of material was dated in an effort to find a fraction of organic material that consistently returned reliable dates. For example, we dated bulk peat samples and also selected individual plant fragments (grasslike blades and rush material) and seeds from peat and organic silt sediments (Table 1). No specific material returned consistently reliable dates, and we concluded that sediments have been frequently contaminated by younger plant roots penetrating from above. This contami- 
Table 1

Radiocarbon Ages Obtained from Big Lagoon Salt Marsh Cores in This Study

\begin{tabular}{|c|c|c|c|c|c|c|}
\hline Sample Name & Field Sample Name & $\begin{array}{c}\text { Laboratory } \\
\text { Identifier (NZA) }\end{array}$ & $\begin{array}{l}\text { Description of } \\
\text { Dated Material }\end{array}$ & Fraction Dated & $\begin{array}{l}\text { Conventional } \\
\text { Radiocarbon } \\
\text { Age (yrs B.P.) }\end{array}$ & $\begin{array}{l}\text { Calibrated } \\
\text { Radiocarbon } \\
\text { Age (yrs B.P.) }\end{array}$ \\
\hline S14: $24-25 \mathrm{~cm}^{*}$ & BLJan13-1: 24-25 cm & 53810 & $\begin{array}{l}\text { Organic clay with numerous } \\
\text { tiny rootlets and fragments } \\
\text { of plant material }\end{array}$ & Peat & Modern & \\
\hline S14: $60 \mathrm{~cm}$ & BLJan13-1: $60 \mathrm{~cm}$ & 53091 & $\begin{array}{l}\text { Organic clay with numerous } \\
\text { tiny rootlets and fragments } \\
\text { of plant material }\end{array}$ & Peat & $437 \pm 18$ & $505-340$ \\
\hline S14: $64-64.2 \mathrm{~cm}$ & BLJan13-1: 64-64.2 cm & 53088 & $\begin{array}{l}\text { Organic clay with numerous } \\
\text { tiny rootlets and fragments } \\
\text { of plant material }\end{array}$ & Peat & $525 \pm 17$ & $535-500$ \\
\hline N6: $63-65 \mathrm{~cm}^{*}$ & BLJan13-2B: $63-65 \mathrm{~cm}$ & 53139 & $\begin{array}{l}\text { Weathered fragment of a cockle } \\
\text { or pipi }\end{array}$ & Shell & $436 \pm 16$ & $520-485$ \\
\hline $\begin{array}{l}\text { N6: } 63-65 \mathrm{~cm} \\
\quad \text { (duplicate)* }^{*}\end{array}$ & BLJan13-2B: $63-65 \mathrm{~cm}$ & 53288 & $\begin{array}{l}\text { Weathered fragment of a cockle } \\
\text { or pipi }\end{array}$ & Shell & $450 \pm 16$ & $525-495$ \\
\hline $\mathrm{N} 7: 51-51.5 \mathrm{~cm}^{*}$ & BLJan13-3: $51-51.5 \mathrm{~cm}$ & 53090 & Rootlets and fibrous plant material & Plant material & Modern & \\
\hline N7: $56-57 \mathrm{~cm}^{*}$ & BLJan13-3: 56-57 cm & 53092 & $\begin{array}{l}\text { Organic clay with numerous tiny } \\
\text { rootlets and fragments of plant } \\
\text { material }\end{array}$ & Peat & $383 \pm 17$ & $485-325$ \\
\hline N7: $91-92 \mathrm{~cm}$ & BLJan13-3: 91-92 cm & 53711 & $\begin{array}{l}\text { Black-brown, humified, } \\
\text { crumbly peat }\end{array}$ & Plant material & $1120 \pm 17$ & $1055-930$ \\
\hline N8: $31-32 \mathrm{~cm}^{*}$ & BLJan13-4: 31-32 cm & 53710 & Light brown organic clay & Plant material & Modern & \\
\hline N8: $69-70 \mathrm{~cm} *$ & BLJan13-4: 69-70 cm & 53692 & Brown organic clay & Sediment & $438 \pm 13$ & $500-345$ \\
\hline N8: $77-78 \mathrm{~cm} *$ & BLJan13-4: 77-78 cm & 53611 & Dark brown organic silt & Plant material & $253 \pm 22$ & $305-150$ \\
\hline N8: 90-91 cm & BLJan13-4: 90-91 cm & 53727 & Long black fibrous reed material & Plant material & $990 \pm 17$ & $950-800$ \\
\hline $\mathrm{N} 1: 58-59 \mathrm{~cm}^{*}$ & BL10/3: 58-59 cm & 55118 & Grasslike fragments & Plant material & Modern & \\
\hline $\mathrm{N} 1: 61-62 \mathrm{~cm}$ & BL10/3: $61-62 \mathrm{~cm}$ & 36402 & Paleosol, laminated organic matter & Peat & $664 \pm 15$ & $650-555$ \\
\hline N1: 90-91 cm & BL10/3: 90-91 cm & 36394 & Paleosol & Peat & $1013 \pm 15$ & $925-805$ \\
\hline $\mathrm{N} 4: 79-81 \mathrm{~cm}$ & BL10/4(BL73): 79-81 & 37704 & Paleosol, laminated organic matter & Peat & $896 \pm 20$ & $795-725$ \\
\hline S13: $81 \mathrm{~cm}^{*}$ & BL10/5: $81 \mathrm{~cm}$ & 55120 & Plant fragments & Plant material & Modern & \\
\hline S13: $84 \mathrm{~cm}^{*}$ & $\mathrm{BL} 10 / 5: 84 \mathrm{~cm}$ & 55121 & Mm-laminae of reed material & Peat & $67 \pm 14$ & $135-30$ \\
\hline S13: $103 \mathrm{~cm}$ & BL10/5: $103 \mathrm{~cm}$ & 36395 & Wood & Wood & $962 \pm 15$ & $905-775$ \\
\hline S13: $130 \mathrm{~cm}$ & BL10/5: $130 \mathrm{~cm}$ & 36403 & Wood & Wood & $979 \pm 15$ & $915-795$ \\
\hline S12: $22-23 \mathrm{~cm}^{\dagger}$ & BL10/6: $22-23 \mathrm{~cm}$ & 36467 & Paleosol & Peat & $333 \pm 15$ & $445-305$ \\
\hline S12: $25-27 \mathrm{~cm}^{*}$ & BL10/6: $25-27 \mathrm{~cm}$ & 55119 & Plant fragments & Plant material & Modern & \\
\hline Probe 13: $133 \mathrm{~cm}$ & Probe 13: $133 \mathrm{~cm}$ & 36396 & Wood within sand & Wood & $994 \pm 15$ & $920-800$ \\
\hline $\mathrm{W} 1: 62-64 \mathrm{~cm}$ & BL53: $62-64 \mathrm{~cm}$ & 34335 & Paleosol, laminated organic matter & Peat & $821 \pm 15$ & $725-675$ \\
\hline N12: $97-98 \mathrm{~cm}^{\dagger}$ & BLOct2013/4: 97-98 cm & 55431 & Plant fragments in gray sediment & Plant material & $1615 \pm 20$ & $1530-1410$ \\
\hline N12: $102-104 \mathrm{~cm}$ & BLOct2013/4: 102-104 cm & 55432 & Plant fragments & Plant material & $1002 \pm 19$ & $925-800$ \\
\hline S15: $69-70 \mathrm{~cm}$ & BLOct2013/6: 69-70 cm & 55433 & Dark brown organic material in clay & Peat & $473 \pm 22$ & $520-465$ \\
\hline S15: $73 \mathrm{~cm}^{*}$ & BLOct2013/6: $73 \mathrm{~cm}$ & 55434 & Plant fragments & Plant material & $519 \pm 19$ & $535-500$ \\
\hline S15: $74-75 \mathrm{~cm}$ & BLOct2013/6: $74-75 \mathrm{~cm}$ & 55435 & Plant fragments & Plant material & $481 \pm 19$ & $525-485$ \\
\hline
\end{tabular}

Ages have been calibrated using OxCal v.4.2 (Bronk Ramsey, 2009) with the southern hemisphere calibration curve (SHCal 13; Hogg et al., 2013). Uncertainties are quoted at $2-\sigma$.

*Sample is probably too young for its stratigraphic context and may represent contamination.

'Sample is probably too old for its stratigraphic position and may represent reworked material.

nation is not surprising given the appearance of several paleosol horizons through the sequence. The reliability of the ages and decisions regarding which dates were used in the OxCal age modeling was assessed using the type of material dated and a combination of consistency with other ages from the same lithofacies and with lithofacies above and below.

Radiocarbon samples were concentrated on bounding the upper contacts of the two paleosols (lithofacies $\mathrm{C}$ and $\mathrm{F}$ ); our goal was to date the time at which the paleoground surface changed. Eight dates have been obtained from within lithofacies C, D, and E. These ages range from 1055-930 cal B.P. to 905-775 cal B.P., with one anomalously older age of 1530-
1409 cal B.P. (Fig. 9). Twelve dates have been obtained from within lithofacies $\mathrm{F}$, and a further nine dates were obtained from the base of lithofacies G. The high number of dates around the upper contact of lithofacies F reflects the difficulty in obtaining a reliable age from this sediment. Lithofacies $\mathrm{F}$ dates span from $\sim 800-500$ cal B.P., and lithofacies $G$ and $G$ (p) ages span from $\sim 530-300$ cal B.P.

\section{Evidence for Tectonic Subsidence}

We infer that the Big Lagoon salt marshes have been affected by tectonic subsidence over the past 1000 yrs. 


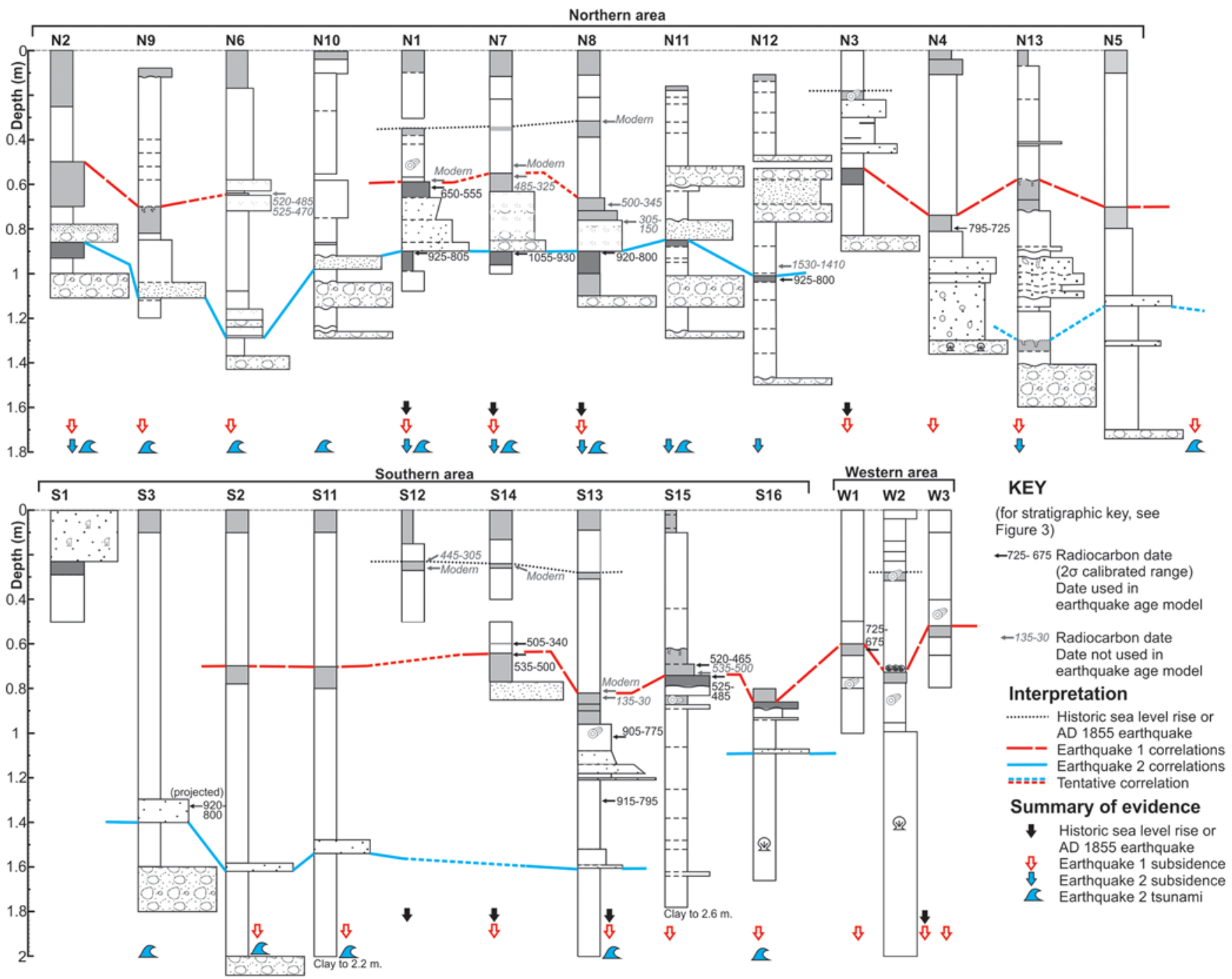

Figure 9. Stratigraphy of the Big Lagoon salt marsh cores with all radiocarbon ages shown. Also shown is the stratigraphic position of earthquakes 1 and 2 and the position of the weak paleosol potentially related to historic sea level rise of the A.D. 1855 Wairarapa earthquake. At the base of each core, we show a summary of the tectonic event evidence preserved in each core. The color version of this figure is available only in the electronic edition.

The primary evidence for this is that the amount of sediment deposited at MHW-MHWS elevations (1.5-1 m) far exceeds the combination of (1) the $0.25 \mathrm{~m}$ elevation range of the MHW-EHWS depositional zones at Big Lagoon (foraminifera provide evidence that most sediment deposited in the Big Lagoon salt marsh cores was deposited at $\sim \mathrm{MHW}$ to EHWS elevations) and (2) the net amount of nontectonic sea level change. Sea level in New Zealand between A.D. 1000 and A.D. 1500 is poorly constrained but is inferred to have been about the same as today at A.D. 1000 and to have fallen to 0.5-0.6 m below present by A.D. 1350 (Figueira, 2012; Hayward, Grenfell, and Sabaa, 2012; Hayward, Grenfell, Sabaa, and Clark, 2012); it then rose again by $0.2-0.3 \mathrm{~m}$ between A.D. 1350 and A.D. 1900 and a further $0.3 \mathrm{~m}$ since A.D. 1900 (Gehrels et al., 2008; Figueira, 2012).

Identification of tectonic subsidence in the Big Lagoon area is consistent with previous work (Brown, 1981; Ota et al., 1995; Hayward, Wilson, et al., 2010; Clark, Hayward, et al., 2011), but in this study we identify two sudden subsidence events that have not been previously recognized. We use the stratigraphic record from Big Lagoon to infer that tectonic subsidence over the past 1000 yrs has primarily occurred during two earthquakes, which we call earthquakes 1 and 2 (Fig. 9). The main evidence for each earthquake is the occurrence of a buried soil and associated elevation change documented by microfossils; earthquake 2 is also associated with a tsunami. We will outline the evidence for each earthquake, from oldest to youngest, using the Nelson et al. (1996) criteria (Table 2), and discuss the age constraints in the following sections.

\section{Earthquake 2}

Earthquake 2 is inferred to have occurred at the boundary between lithofacies $\mathrm{C}$ (with its well-developed paleosol 
Table 2

Strength of Evidence for Coseismic Subsidence

\begin{tabular}{|c|c|c|c|}
\hline Criteria & Earthquake 2 (879-798 yrs B.P.) & Earthquake 1 (518-472 yrs B.P.) & $\begin{array}{c}\text { Historic Sea Level Rise or A.D. } 1855 \\
\text { Wairarapa Earthquake }\end{array}$ \\
\hline 1. Suddenness of submergence & $\begin{array}{l}\text { Yes: sharp contacts at top of } \\
\text { paleosol and rapid microfossil } \\
\text { assemblage change }\end{array}$ & $\begin{array}{l}\text { Yes: sharp contacts at top of } \\
\text { paleosol and rapid microfossil } \\
\text { assemblage change }\end{array}$ & $\begin{array}{l}\text { No: weak paleosol with a } \\
\text { typically gradational upper } \\
\text { contact }\end{array}$ \\
\hline 2. Amount of submergence & $\begin{array}{l}\text { Yes: microfossil evidence of } \\
0.45 \mathrm{~m} \text { submergence }\end{array}$ & $\begin{array}{l}\text { Yes: microfossil evidence of } \\
0.25 \mathrm{~m} \text { submergence }\end{array}$ & $\begin{array}{l}\text { Equivocal: possibly } \leq 0.3 \mathrm{~m} \text { of } \\
\text { submergence but not } \\
\text { constrained by microfossils }\end{array}$ \\
\hline 3. Lateral extent of submerged soil & $\begin{array}{l}\text { No: buried soil has limited extent } \\
\text { in northern area }\end{array}$ & $\begin{array}{l}\text { Yes: buried soil in northern, } \\
\text { southern and western areas }\end{array}$ & $\begin{array}{l}\text { Equivocal: weak buried soil in all } \\
\text { areas but has patchy occurrence }\end{array}$ \\
\hline 4. Coincidence with tsunami deposits & $\begin{array}{l}\text { Yes: tsunami deposit overlies } \\
\text { paleosol }\end{array}$ & No & No \\
\hline 5. Regional synchroneity & $\begin{array}{l}\text { No correlation to other peat-mud } \\
\text { contacts but correlation with an } \\
\text { upper plate fault rupture }\end{array}$ & $\begin{array}{l}\text { No correlation to other peat-mud } \\
\text { contacts but possible } \\
\text { correlation to regional } \\
\text { paleotsunami deposits }\end{array}$ & $\begin{array}{l}\text { No correlation to other peat-mud } \\
\text { contacts, possible correlation } \\
\text { with A.D. } 1855 \text { earthquake or } \\
\text { twentieth-century sea level rise }\end{array}$ \\
\hline
\end{tabular}

An evaluation of the strength of evidence for coseismic subsidence in relation to earthquakes 1 and 2, and historic sea level rise or A.D. 1855 Wairarapa earthquake at Big Lagoon with regard to the criteria of Nelson et al. (1996).

in the northern area) and the overlying sand of lithofacies D or the mud of lithofacies E (Fig. 9). The varying stratigraphic expressions of earthquake 2 are shown in Figure 7 and the spatial extent of the evidence in Figure 10a,b.

Microfossils within lithofacies $\mathrm{C}$ confirm a soil environment with brackish soil diatoms and low-salinity EHWS foraminifera assemblages. These indicate the sites where lithofacies $\mathrm{C}$ is present were within reach of the highest spring tides. Evidence that the cessation of soil development in lithofacies $\mathrm{C}$ was caused by earthquake-driven subsidence includes the following:

1. Suddenness. Abrupt sedimentary change from lithofacies $\mathrm{C}$ to lithofacies D or E. A gradual change would indicate a slow process such as eustatic sea level rise. The abrupt change indicates a sudden rise in relative sea level, consistent with an earthquake.

2. Amount. Microfossil evidence of a change in depositional elevation from low salinity, EHWS salt marsh in lithofacies C to MHW salt marsh in lithofacies E, as demonstrated in cores $\mathrm{N} 2$ and N6. This change indicates a rise in relative sea level consistent with tectonic subsidence. (The amount of subsidence is more fully described in the Quantifying Earthquake 2 Vertical Displacement section.)

3. Lateral extent. Lithofacies $\mathrm{C}$ is not laterally extensive; it is restricted to the northern salt marsh and is only present in half of the cores in this area (Fig. 10a). The restricted and patchy presence of lithofacies C may be due to (1) paleotopography of the marsh surface, which meant lithofacies C only occurred on high points and, like the present day, a well-developed soil can lie immediately adjacent to the lagoon shoreline or the shoreline of an ephemeral pond where no soil is developing, or (2) lithofacies $\mathrm{C}$ was formerly more widespread but in some places was eroded by a tsunami (see below). Tsunami are known to scour some areas and create deposits nearby (e.g., Morton et al.,
2011; Richmond et al., 2011), with the pattern of erosion and deposition strongly influenced by pre-existing topography, vegetation, and, in the case of Big Lagoon, probably the topography of the barrier. The sharp base of lithofacies $\mathrm{D}$ in some areas of the northern area (e.g., see photo of core N9 in Fig. 7) is compatible with erosional scour.

4. Coincidence with tsunami deposits: Lithofacies $\mathrm{C}$ is often overlain by an inferred tsunami sand deposit (lithofacies D, see justification below).

5. Synchroneity: In terms of regional synchroneity of submergence, similar paleosol-silt contacts have not been described at other sites in the region (Hayward, Grenfell, Sabaa, Kay, et al., 2010; Hayward, Grenfell, Sabaa, and Kay, 2010; Hayward et al., 2011; Clark, Hayward, et al., 2011), but as we shall discuss in the Seismic Sources section, there are correlations to regional tectonic events.

\section{Tsunami Coincident with Earthquake 2}

Lithofacies $\mathrm{D}$ is most likely to have been deposited by a tsunami. Characteristics that indicate a tsunamigenic source (e.g., Dominey-Howes et al., 2006; Morton et al., 2007; Peters and Jaffe, 2010; Goff et al., 2012) include (1) mixed microfossil assemblages, (2) an anomalously coarse grain size, (3) sharp basal contact, (4) thinning and fining of the deposit inland, and (5) its uneven depth indicating it mantled topography rather than infilling it. (6) We also describe how lithofacies D differs from modern storm deposits. We further describe each of these characteristics below.

1. Mixed microfossil assemblage. As described previously in the Paleoenvironmental Interpretation section, lithofacies D has foraminiferal assemblages displaying a mix of openocean salinity, exposed coast shelf species, and brackishmarine sheltered subtidal-intertidal species. The mixed assemblages imply portions of the sand were entrained from both landward and seaward of its current depositional 
(a)

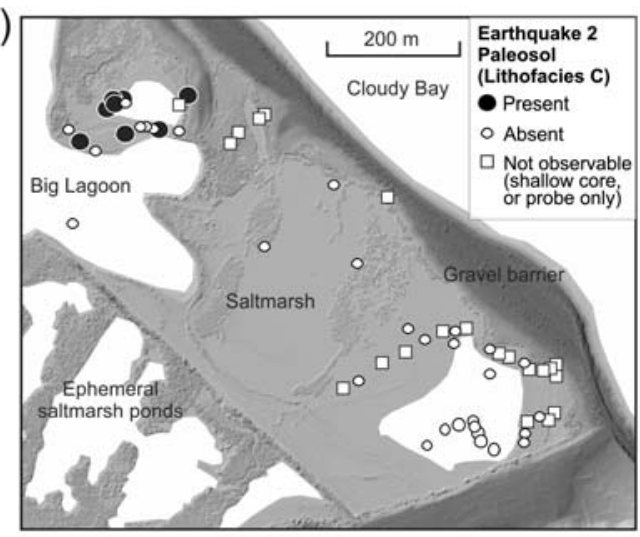

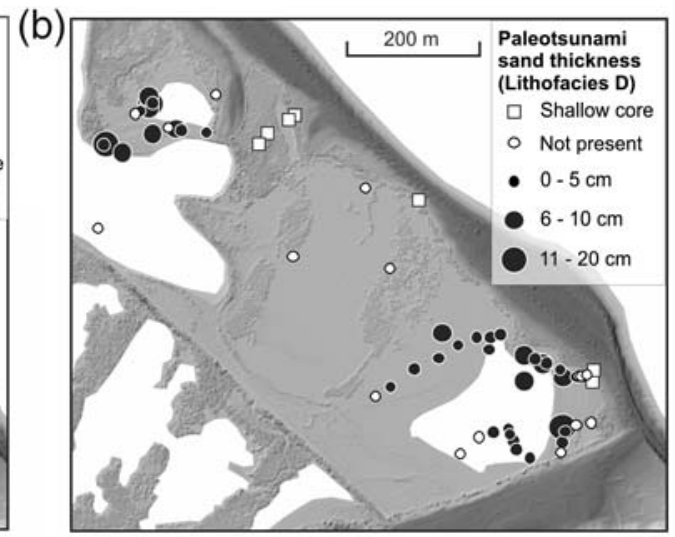

(c)

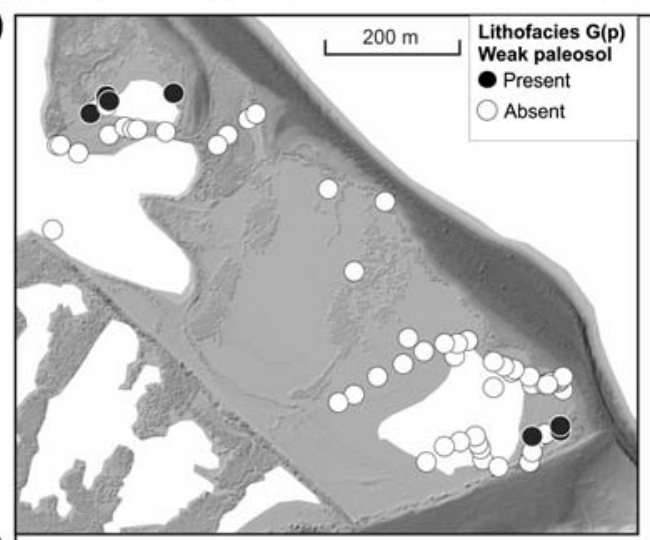

(d)

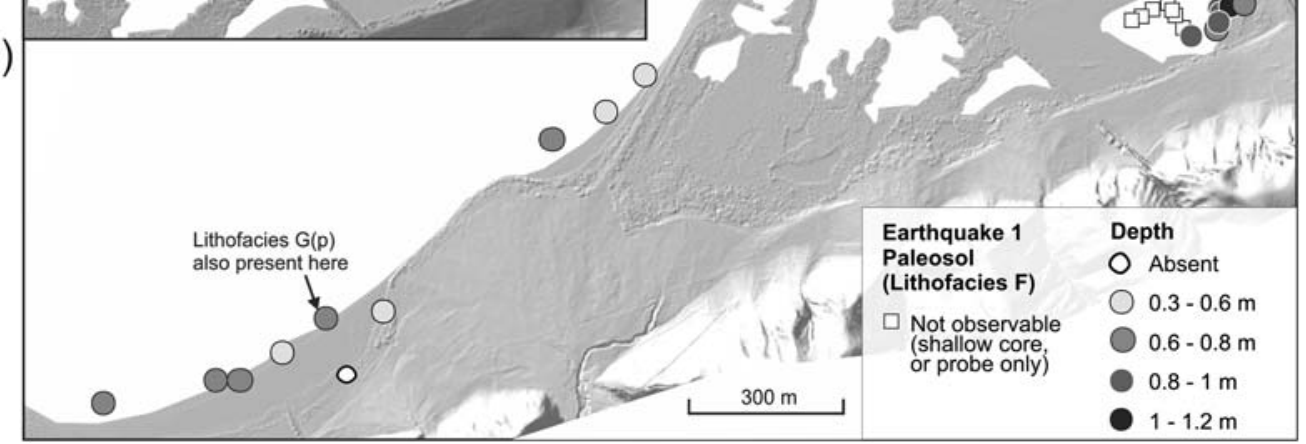

Figure 10. (a) The spatial extent of lithofacies $C$, the buried paleosol representing earthquake 2 subsidence. (b) The spatial extent and thickness of lithofacies D, the tsunami deposit associated with earthquake 2. (c) The spatial extent of lithofacies G(p), the weak paleosol that probably represents either historic eustatic sea level rise or subsidence in the A.D. 1855 Wairarapa earthquake. Base maps for (a)-(c) are LiDAR images shaded by elevation; see Figure $2 d$ for elevation scale. (d) The spatial extent and depth of lithofacies F, the buried paleosol representing earthquake 1 subsidence. Each of these maps contains data from more cores than we have presented in Figure 3; (E) the stratigraphy of most extra cores are in Figure S2. The base map of (d) is a shaded LiDAR digital elevation model.

location (Fig. 8). Such mixtures of offshore- and landwardsourced foraminifera assemblages have been observed in modern tsunami deposits (e.g., Hawkes et al., 2007). We suggest the offshore, open-coast, subtidal foraminifera were entrained by the incoming tsunami waves, and lagoon-dwelling foraminifera were entrained by the outgoing tsunami waves. Lithofacies D also contains a proportion of salt marsh foraminifera that could have been incorporated by tsunami erosion or be later infaunal colonists of the emplaced sand. Diatoms of lithofacies D were only studied in core $\mathrm{N} 1$, but the mixture of flora from different habitats (marine plankton through to fresh-brackish soils) is consistent with the tsunami origin (Fig. 5).
2. Anomalous grain size. Lithofacies D consistently has a coarser grain size than the surrounding sediment (Fig. 3). In core $\mathrm{N} 9$, grain size change was measured over a suite of 19 samples spanning from $10 \mathrm{~cm}$ below the base of lithofacies $\mathrm{D}$, through lithofacies $\mathrm{D}$, and into the lower $20 \mathrm{~cm}$ of lithofacies E (Fig. 6). Lithofacies B, underlying the tsunami deposit at this site, is dominated by silt and clay, whereas lithofacies D is markedly coarser, with a dominance of fine and coarse sand. The pronounced bimodal peak in the grain-size distribution histograms of lithofacies D is intriguing; one possibility is that the coarse sand fraction is from offshore and the fine sand fraction was sourced from the lagoon. The basal part 
of lithofacies $\mathrm{E}$ is dominated by fine sand, with an upward increase in the proportion of silt and clay. This upward fining may reflect post-tsunami redistribution of coarse sediment in the lagoon or postdepositional bioturbation between the tsunami sand and overlying clay.

3. Sharp basal contact. Lithofacies D typically has a sharp basal contact, which is a typical characteristic of modern tsunami deposits (Figs. 3 and 7; e.g., Hawkes et al., 2007, Peters and Jaffe, 2010). We do not see the presence of ripup clasts along the basal contact, which is also a characteristic of tsunami deposits; however, given the deposit is only exposed in core samples, this is not surprising. The upper contact of lithofacies D varies from gradational to sharp (Figs. 3 and 7).

4. Thinning of deposit inland. Figure 10b shows the distribution and thickness of lithofacies D. In the southern area, lithofacies D thins inland and is generally not present at distances $>360 \mathrm{~m}$ from the barrier. Specific examples of seaward-to-landward core sequences that illustrate the inland thinning of lithofacies D have been described in the Results section for the southern area. Inland thinning of lithofacies D is not distinguishable in the northern area where the layer thickness is more heterogeneous.

5. Topographic mantling. A characteristic of tsunami deposits is that they mantle topography (Morton et al., 2007). The variable depth of lithofacies D in the northern area (top at 1.2-0.8 $\mathrm{m}$ depth) and southern area (top at 1.6-1.1 m depth, Fig. 3) is consistent with topographic mantling rather than topographic infilling.

6. Dissimilarity to storm deposits. Lithofacies D displays significantly different sedimentology from the modern storm deposits that were observed in core S1 and at several other locations along the Wairau Bar. A modern storm deposit in core S1 was characterized by well-sorted coarse sand that was barren of foraminifera (as is the present-day intertidal beach), in contrast to lithofacies $\mathrm{D}$, which has a high abundance of foraminifera and variable grain size. Modern storm deposits at core site S1 and at a site $2 \mathrm{~km}$ along the Wairau Bar (Fig. 2a) form lobes extending only 30-40 m inland from the high-tide line, whereas lithofacies D extends up to $360 \mathrm{~m}$ inland from the high-tide line. Further evidence that lithofacies $\mathrm{D}$ is not a storm deposit is that it contains foraminifera from the subtidal parts of the lagoon, and storm waves are highly unlikely to reach, let alone entrain sediment from, subtidal depths of the lagoon.

The extent and physical properties of paleotsunami deposits can be used to derive parameters of the tsunami itself. For example, the extent of sedimentary deposits inland can give minimum estimates of the tsunami inundation distance and runup elevation (e.g., Minoura et al., 2001; Kelsey et al., 2005). The maximum inland extent of the paleotsunami deposit in the southern area is $360 \mathrm{~m}$ inland from the modern high-tide line; and, in the northern area, the deposit extends at least $345 \mathrm{~m}$ inland (Fig. 10b). Tsunami inundation probably extended $\geq 360 \mathrm{~m}$ inland, but sand deposition ceased due to decreasing flow speeds. The incorporation of foraminifera from subtidal lagoon environments into the tsunami sand suggests the tsunami inundated further into the lagoon because subtidal lagoon environments only occur inland of the present extent of paleotsunami sand deposition.

The tsunami wave height at the shoreline was probably $>3.3 \mathrm{~m}$ above MSL. The crest elevation of the gravel bar in the modern day is $\sim 3.7-3.8 \mathrm{~m}$ above MSL adjacent to the Big Lagoon salt marsh (Fig. 2d). If the gravel bar crest elevation was approximately the same height in the past when earthquake 2 occurred, then the tsunami wave height must have been $>3.3 \mathrm{~m}$ to overtop the bar (taking into account $\sim 0.5 \mathrm{~m}$ of tectonic subsidence immediately prior to the tsunami; see the Quantifying Earthquake 2 Vertical Displacement section). The microfossil record does not show any indications that the bar was lower than the present in the past (e.g., by showing increased salinity or more frequent storm incursions), therefore it seems reasonable to assume the bar crest elevation of $\sim 3.8 \mathrm{~m}$ is an equilibrium height that was probably similar in the past.

\section{Quantifying Earthquake 2 Vertical Displacement}

We estimate $0.45 \pm 0.1 \mathrm{~m}$ of tectonic subsidence associated with earthquake 2 . This is based on the change from an EHWS salt marsh environment in lithofacies $\mathrm{C}$ to an MHW salt marsh environment in lithofacies $\mathrm{E}$, with up to $0.15 \mathrm{~m}$ of sand deposited in between in cores N2 and N6 (Fig. 11). The amount of displacement was estimated by taking the MAT-derived elevations for a sample at the top of lithofacies $\mathrm{C}$ and a sample at the base of lithofacies E; we calculated the difference in MAT-derived elevation between the samples and then added the depth of sediment in between the two samples. Samples within lithofacies D were not used due to transported foraminifera in the tsunami sand. (E) For a detailed description of how the amount of $0.45 \pm 0.1 \mathrm{~m}$ was calculated, see the description in the electronic supplement.

Accurately quantifying displacements using foraminifera at Big Lagoon has proven difficult due to (1) low foraminiferal abundances in postearthquake sediments (for further discussion, (E) see the electronic supplement), (2) contamination by transported and deep infaunal-living foraminifera, and (3) because the amount of displacement is small, the change in paleoenvironment was so minor as to not be captured in most cores. Elevation-related foraminiferal zones are far broader in the unvegetated intertidal (below MHW) and shallow subtidal environments. At the time of earthquake 2, much of the southern area was accumulating sediment at these unvegetated lower elevations (Ammonia-dominated assemblages). Thus the lithofacies $\mathrm{C}$ horizon is absent and foraminiferal changes are insufficient to accurately document the small amount of displacement that occurred during earthquake 2 in the southern area. 


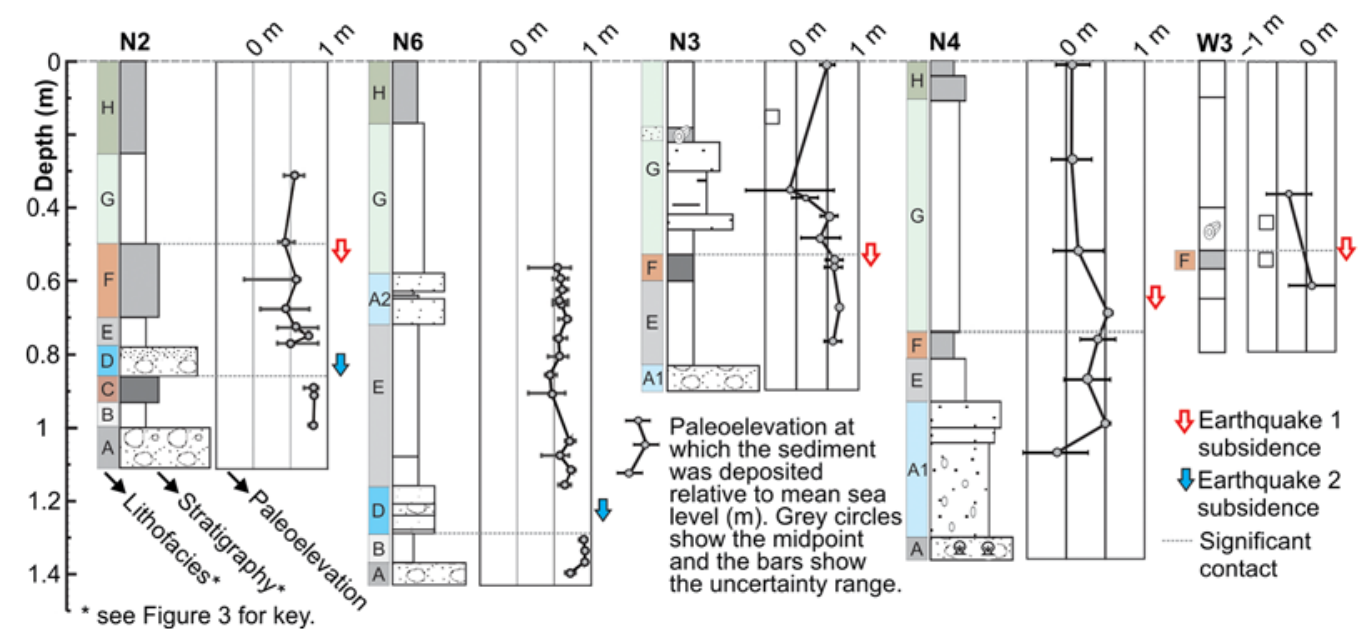

Figure 11. Paleoelevation plots (relative to MSL) for selected Big Lagoon salt marsh cores based on foraminiferal assemblages. The paleoelevations were estimated using the modern analog technique (MAT), based on the relative abundance of benthic foraminiferal species in samples with $>30$ specimens (Hayward et al., 2004). See the Methods section for a description of MAT and how the associated uncertainties are calculated. Square boxes show where samples were examined but did not contain sufficient foraminifera to generate a reliable paleoelevation estimate. Samples from lithofacies D in cores N2 and N6 were removed from the analysis because they contained high proportions of transported open marine subtidal faunas. Arrows show the location of interpreted subsidence events. The color version of this figure is available only in the electronic edition.

Age of Earthquake 2

Seven radiocarbon ages have been used to constrain the age of earthquake 2 as $880-800$ cal B.P. (Fig. 12). Four dates were obtained from lithofacies $\mathrm{C}$, the paleosol that was at the ground surface at the time of the earthquake; these ages cluster around $920-800 \mathrm{cal}$ B.P., with one slightly older at 1055-930 cal B.P. (Fig. 9). One date of 920-800 cal B.P. was obtained from a small piece of wood within the tsunami sand (lithofacies D); we assume this wood was from a tree that was killed and entrained by the tsunami. Two ages that postdate the earthquake are from core S13 and have ages of $900-775$ cal B.P.; the ages were obtained from wood fragments 25 and $60 \mathrm{~cm}$ above the tsunami deposit in the southern area (Fig. 9). A significantly older date of 15301410 cal B.P., obtained from the base of lithofacies $\mathrm{E}$ in core N12, was discounted as it is probably older reworked material.

\section{Earthquake 1}

Earthquake 1 is defined by the rapid and widespread change from lithofacies $\mathrm{F}$ to lithofacies $\mathrm{G}$ (Figs. 7 and 9). The earthquake caused subsidence, which in places saw an MHW-EHWS salt marsh soil or organic-rich clay (lithofacies F) overlain by clay deposited at a lower elevation (lithofacies G). There is no evidence at Big Lagoon that earthquake 1 was accompanied by a tsunami.

Evidence that the change from lithofacies $F$ to lithofacies $\mathrm{G}$ was caused by earthquake-driven subsidence includes the following:
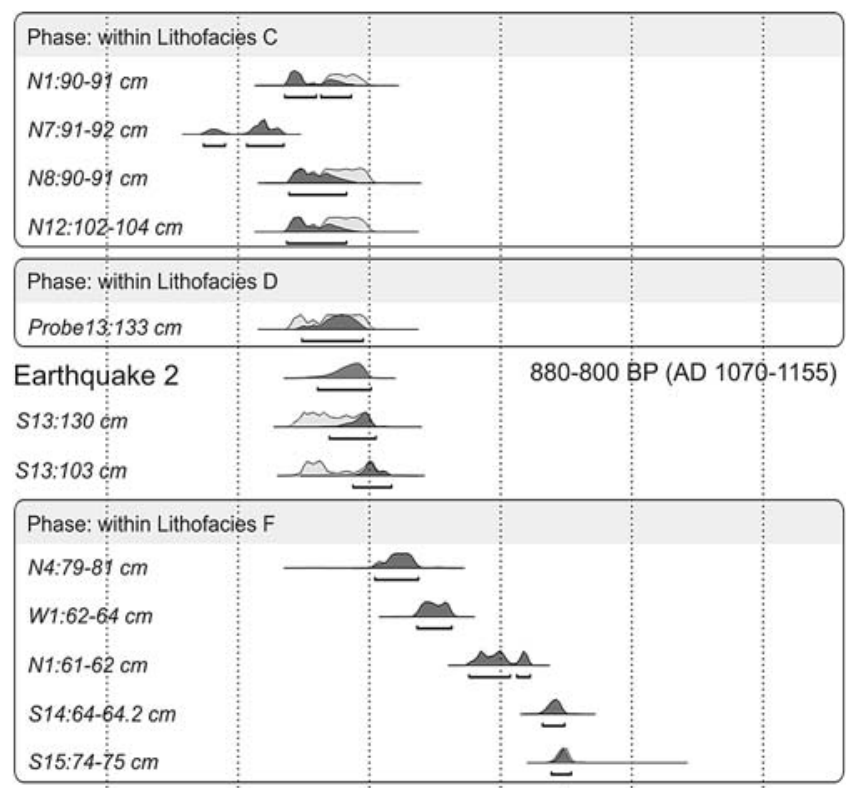

Earthquake 1: 520:470 BP (AD 1430-1480)

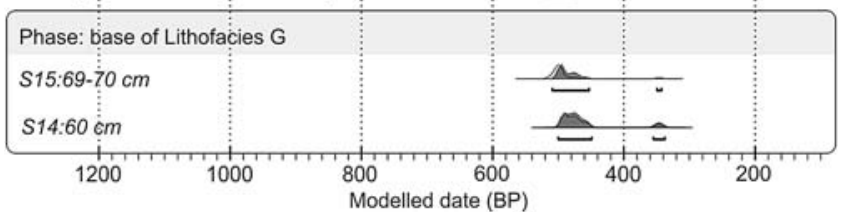

Figure 12. Age model showing the estimated age of earthquakes 1 and 2. Age modeling was undertaken in OxCal (Bronk Ramsey, 2009); (E) the OxCal code, and the model output table are available in the electronic supplement. 
1. Suddenness. Abrupt sedimentary change from lithofacies F to lithofacies G; the contact between these lithofacies is typically sharp and often bioturbated (Fig. 7).

2. Amount. Microfossil evidence of a change in depositional elevation from low salinity, MHW-EHWS salt marsh in lithofacies F to MSL-MHW salt marsh in lithofacies G. This change indicates a rise in relative sea level, probably caused by tectonic subsidence. The amount of subsidence is more fully described in the Quantifying Earthquake 1 Displacement section.

3. Lateral extent. The widespread occurrence of lithofacies $\mathrm{F}$ and the similarity in ages obtained from this lithofacies throughout the area (Figs. 9 and 10d) indicates that the cessation of accumulation of this lithofacies was a synchronous, salt-marsh-wide event that is consistent with an earthquake. Conversely, it is inconsistent with localized salt marsh changes such as lagoon beach migrations and enclosure of salt marsh ponds.

4. Coincidence with tsunami. We do not recognise a tsunami deposit associated with this earthquake, although, as will be discussed later, there are temporal correlations with paleotsunami deposits in other parts of the wider area.

5. Synchroneity. There are no known similar paleosol-silt contacts during this time period at other sites in the region (Hayward, Grenfell, Sabaa, Kay, et al., 2010; Hayward, Grenfell, Sabaa, and Kay, 2010; Hayward et al., 2011; Clark, Hayward, et al., 2011).

Lithofacies $\mathrm{F}$ is not typically a well-developed paleosol (in contrast to lithofacies $\mathrm{C}$, which formed prior to earthquake 2; Fig. 7), and this probably reflects either its formation at a slightly lower elevation than lithofacies $\mathrm{C}$ or a less mature soil. The only locations where lithofacies $\mathrm{F}$ shows soil development is in cores S15 and S16 (Fig. 7); the upper contact in these cores is very sharp, and the paleosol is overlain by finely laminated dark brown clay. We interpret this contact as a change from salt marsh soil to a pond; the laminated clay probably accumulated in shallow, standing water.

\section{Quantifying Earthquake 1 Displacement}

We estimate the amount of tectonic subsidence associated with earthquake 1 is $0.25 \pm 0.1 \mathrm{~m}$ (Fig. 11). The amount of subsidence has been determined using MAT estimates from foraminiferal assemblages in four cores: N2, N3, N4, and W3 (Fig. 11). The amount of displacement was calculated in the same manner as for earthquake 2 (described above), except contamination by tsunami sediments did not have to be accounted for. (E) A detailed description of how the amount of $0.25 \pm 0.1 \mathrm{~m}$ was calculated (see the Description of the Quantification of Vertical Deformation for Earthquakes 1 and 2 section in the electronic supplement), and here we summarize the results.

Core $\mathrm{N} 2$ shows subsidence of $0.25 \pm 0.15 \mathrm{~m}$ and core N4 shows subsidence of $\sim 0.35 \mathrm{~m}$ (Fig. 11). Core N3 shows $\sim 0.25 \mathrm{~m}$ of subsidence at the lithofacies $\mathrm{F}-\mathrm{G}$ contact; the
MAT-derived elevation curve for core N3 also suggests an $\sim 0.5 \mathrm{~m}$ of sea level fall within a relatively coarse-grained section of lithofacies $G$, but the inability to correlate the sea level fall to other cores implies it is a local anomaly, perhaps due to transported foraminifera. Core W3 shows subsidence of $\sim 0.65 \pm 0.8 \mathrm{~m}$ at the lithofacies $\mathrm{F}-\mathrm{G}$ contact. This larger estimate of subsidence in the western area may reflect contributions from sediment compaction and the greater inaccuracy of MAT estimates in the intertidal sediments of this area. Unlike the northern area, which is underlain by gravel at $>1.5 \mathrm{~m}$, the western area is underlain by silt to a depth of at least $3.5 \mathrm{~m}$ (E) see extended W2 core log in Fig. S3); this deeper sequence of silt probably underwent a degree of compaction during earthquake 1 , hence the larger amount of apparent subsidence recorded in W3.

In summary, the MAT paleoelevation estimates indicate subsidence of $0.25 \pm 0.1 \mathrm{~m}$ occurred at the lithofacies $\mathrm{F}-\mathrm{G}$ boundary, the northern salt marsh. The western area underwent a greater amount of subsidence, possibly due to sediment compaction. There are a number of other cores where we examined foraminiferal samples across the lithofacies F-G contact but did not find reliable evidence of elevation change. The primary reason for this was the absence or extremely low abundances of fauna, particularly in the southern area (Fig. 5).

\section{Age of Earthquake 1}

The age of earthquake 1 is estimated at 520-470 cal B.P. (Fig. 12). The age model uses seven radiocarbon ages: five pre-earthquake ages from lithofacies $\mathrm{F}$ and two postearthquake ages from the base of lithofacies G (Fig. 12). In total we obtained nine ages from lithofacies $\mathrm{F}$ and six ages from the base of lithofacies $\mathrm{G}$, but there is a high proportion of anomalously young or modern age samples in these lithofacies, and eight of the fifteen ages obtained have been discounted (Fig. 9).

Of the nine ages from within lithofacies $\mathrm{F}$, five ages were considered reliable with another two ages possibly reliable. The five reliable ages range from 795-725 cal B.P. to 525485 cal B.P. The older ages were obtained from the middle and base of lithofacies $\mathrm{F}$ so probably reflect the early stages of sediment accumulation. Three dates from the top of lithofacies F cluster around $650-500$ cal B.P. Dates of 305$150 \mathrm{cal}$ B.P. and $135-30 \mathrm{cal}$ B.P. were rejected as they are anomalously young and are assumed to reflect sample contamination by young plant roots. The two possibly reliable lithofacies $\mathrm{F}$ dates of $485-325 \mathrm{cal}$ B.P. and 500-345 cal B.P. were rejected from our age model; the former date was obtained just above the anomalously young date of $305-150 \mathrm{cal}$ B.P., leading to suspicion that the whole unit was contaminated by young plant roots, and the latter age was obtained from a sample noted to contain numerous plant roots. Inclusion of the two possibly reliable ages would shift the age estimate of earthquake 1 only slightly, making it $\sim 20$ yrs younger. 
Of the six dates from the base of lithofacies G, three returned modern ages and are assumed to represent contamination, and the other three ages cluster around 530-400 yrs B.P. and are consistent with slightly postdating lithofacies $\mathrm{F}$ (Fig. 9). Our age model uses the ages 505-340 cal B.P. from core S14 and 520-465 cal B.P. from core S15 $(69-70 \mathrm{~cm}$; Fig. 12). The age model does not include the age of 535500 cal B.P. from core S15 $(73 \mathrm{~cm})$ because this age is slightly older than the two surrounding ages and could represent organic matter reworked from lithofacies $\mathrm{F}$ below; however, when it was be included, it made negligible difference to the earthquake age.

\section{Evidence for A.D. 1855 Wairarapa Earthquake or Historical Sea Level Rise}

A weak paleosol, lithofacies G(p), with microfossils indicative of a low salinity, brackish soil environment, is present in many cores at a depth of $\sim 30 \mathrm{~cm}$ (Figs. 3, 7, and 10c). We interpret this paleosol as evidence of either subsidence in the A.D. 1855 Wairarapa earthquake or recent (past $100 \mathrm{yrs)} \mathrm{eustatic} \mathrm{sea} \mathrm{level} \mathrm{rise.} \mathrm{The} \mathrm{patchy} \mathrm{occurrence}$ of lithofacies $\mathrm{G}(\mathrm{p})$, along with the gradational upper contact and lack of well-constrained microfossil evidence of elevation change mean this buried incipient soil does not present a strong case for earthquake-related subsidence (Table 2), but other evidence in the form of historic accounts of subsidence and correlation to buried soils around the inland margins of Big Lagoon mean the case for coseismic subsidence is possible.

Historic accounts and maps confirm the lower Wairau Valley area underwent subsidence in the Wairarapa earthquake (Grapes and Downes, 1997), and buried soils at depths of 0.1-0.3 m depth around the margins of Upper Lagoon and Chandlers Lagoon have been documented by Hayward, Wilson, et al. (2010) and Clark, Hayward, et al. (2011). It is uncertain if the observed subsidence of Big Lagoon in A.D. 1855 was due to liquefaction and sediment compaction or to tectonic subsidence (Grapes and Downes, 1997). Hayward, Wilson, et al. (2010) favor liquefaction-driven subsidence due to the small spatial extent of their observed buried soil, whereas Clark, Hayward, et al. (2011) favored a mixed mechanism, noting that evidence of subsidence was widespread around Big Lagoon but of variable amounts.

Our observation of a buried weak paleosol at $\sim 0.3 \mathrm{~m}$ below the modern salt marsh surface is compatible with evidence of subsidence in A.D. 1855. The paleosol is perhaps more likely to be a record of tectonic subsidence (versus sediment compaction or liquefaction-related subsidence) because there is no evidence of liquefaction-susceptible fine sands at most core sites where the paleosol is seen, and most cores have gravel at shallow depths, suggesting sediment compaction would be limited.

Lithofacies $G(p)$ could, however, equally be evidence of twentieth-century sea level rise. Gehrels et al. (2008) and Grenfell et al. (2012) have documented an $\sim 0.3 \mathrm{~m}$ rise in sea level at two tectonically stable sites in northern and southern New Zealand since $\sim$ A.D. 1900. The age control for lithofacies $G(p)$ is poor. Three of the four samples were obtained from lithofacies $\mathrm{G}(\mathrm{p})$ returned modern ages, and one is $445-305$ cal B.P. Given the stratigraphic position of the samples at $0.25-0.3 \mathrm{~m}$ deep, it is not surprising that modern ages were obtained from this lithofacies because it is within reach of modern salt marsh plant roots. The age of 445-305 cal B.P. may be reworked or may represent the true age of the sediment. If the latter is the case, then this age supports neither the Wairarapa earthquake or a twentieth-century sea level rise scenario, and it may instead represent an earlier period of eustatic sea level rise.

\section{Seismic Sources}

Big Lagoon is surrounded by numerous active upper plate faults (Fig. 13) and underlain by the southern Hikurangi plate interface (Fig. 1b). Each of these are potential seismic and tsunamigenic sources that could impact the study site (Stirling et al., 2012; Power, 2013). The seismic sources of earthquakes 1 and 2 are unknown but can be explored using a combination of existing upper plate fault paleoearthquake histories, earthquake deformation modeling, and tsunami modeling. A compilation of regional upper plate fault paleoearthquakes, marine terrace uplift events, and paleotsunami is shown in Figure 13.

\section{Earthquake 2}

We propose that earthquake 2 was caused by rupture of the southern Hikurangi subduction interface, with possible synchronous rupture of the Wairarapa fault. This reasoning is guided by dislocation modeling of slip on the plate interface (Fig. 14) and a comparison of the age of earthquake 2 with regional upper plate earthquakes (Fig. 13).

Elastic half-space dislocation modeling of a southern Hikurangi subduction earthquake scenario, based on the present-day pattern of interseismic locking (Wallace and Beavan, 2010; Fig. 14a), predicts that the Big Lagoon area would subside (Fig. 14b). Amounts of subsidence vary depending on the detailed slip distribution, but an event releasing 500 yrs of accumulated elastic strain, using the current distribution of slip deficit accumulation as a guide to produce the slip model, may produce $\sim 0.5 \mathrm{~m}$ of subsidence (Fig. 14b), similar to the amount of subsidence recorded for earthquake 2 at Big Lagoon. Rupture of the subduction interface is also compatible with a southern Hikurangi subduction interface earthquake-triggered tsunami inundating the Cloudy Bay coastline (Fig. 15a).

The age of earthquake 2 correlates with the timing of several tectonic events on upper plate faults of the southern Hikurangi margin (Fig. 13). The timing of uplift of Taupo Swamp has a wide age uncertainty and probably correlates with the 1000-1050 cal B.P. rupture of the nearby Ohariu fault (Litchfield et al., 2004; Cochran et al., 2007). The 


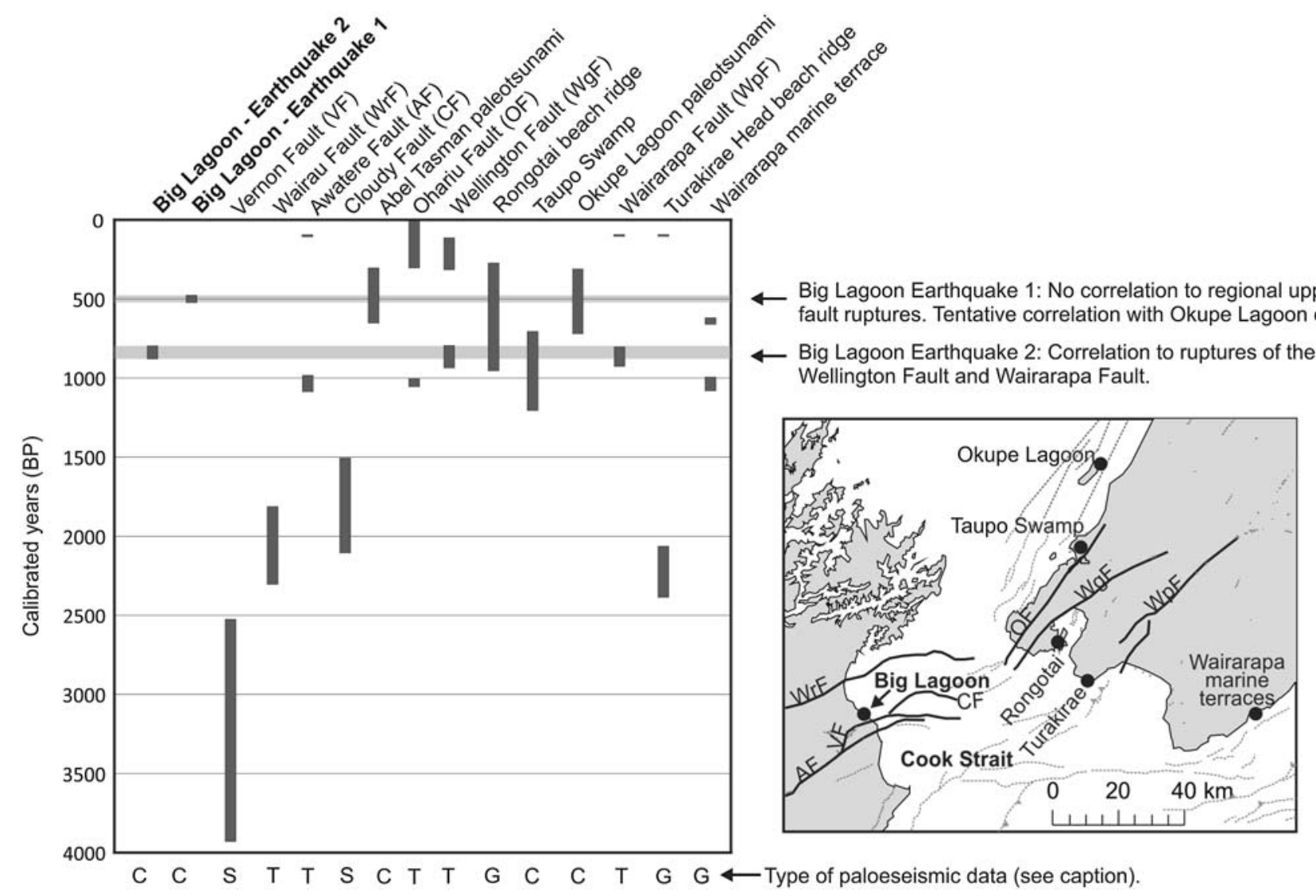

Figure 13. Compilation of paleoseismic events ages from the northern Marlborough-Wellington region, and comparison with the ages of earthquakes 1 and 2 at Big Lagoon. The inset map shows the data locations (except Abel Tasman, which is shown on Fig. 1a) and the main upper plate faults for which we have shown paleoearthquakes ages (bold lines); minor faults or faults for which there are no paleoearthquake data are shown in dashed, gray lines. The type of paleoseismic data obtained from each site or fault varies: C, core (the paleoearthquake or paleoseismic evidence is preserved in core samples); $\mathrm{S}$, seismic (the paleoearthquake evidence has been obtained from high-resolution offshore seismic lines); T, trench (paleoearthquake evidence obtained from multiple paleoseismic trenches); G, geomorphology (paleoearthquake data obtained from geomorphological features such as beach ridges and marine terraces). Seismic event ages were obtained from the following sources: Vernon fault (Pondard and Barnes, 2010); Wairau fault (Barnes and Pondard, 2010; Nicol et al., 2011); Awatere fault (Mason et al., 2006); Cloudy fault (Pondard and Barnes, 2010); Wairarapa fault (Little et al., 2009); Turakirae beach ridges (McSaveney et al., 2006); Wellington fault (Langridge et al., 2011); Ohariu fault (Litchfield et al., 2006; Litchfield, Van Dissen, et al., 2010); Okupe Lagoon and Taupo Swamp (Cochran et al., 2007); Rongotai beach ridge (Pillans and Huber, 1995); and Abel Tasman paleotsunami (Goff and Chagué-Goff, 1999).

(a)

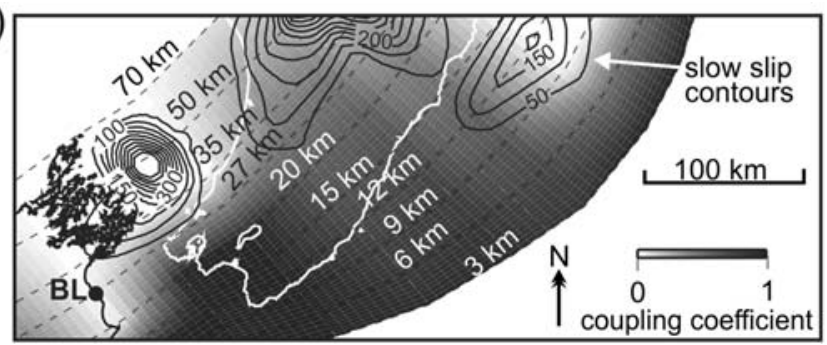

(b)

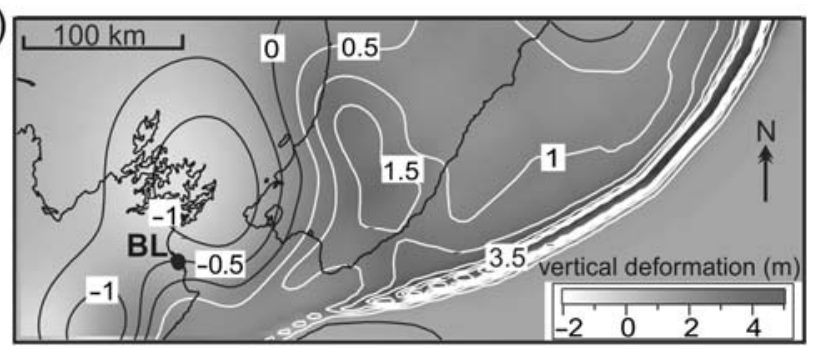

Figure 14. (a) Coupling coefficient on the southern Hikurangi subduction interface determined from campaign Global Positioning System (GPS) measurements over the last $15 \mathrm{yrs}$; the velocities used average through slow-slip events. Black contours show total slip (in mm) detected in slow-slip events on the Hikurangi subduction interface since 2002 using continuous GPS data. Dashed black lines show depth contours (labeled) to the subduction interface; BL, Big Lagoon. (Figure modified from Wallace and Beavan, 2010.) (b) Upper plate deformation produced by a plausible southern Hikurangi subduction interface earthquake scenario. Here, we use elastic dislocation, half-space modeling of a subduction earthquake scenario with $500 \mathrm{yrs}$ of accumulated slip based on the present-day pattern of interseismic locking shown in (a). White contours show areas of uplift, black contours show areas of subsidence (contour intervals are $0.5 \mathrm{~m}$, and labeled in meters). The amount of upper plate deformation scales with the recurrence interval modeled; in this example, an event releasing 500 yrs of accumulated elastic strain produces $\sim 0.5 \mathrm{~m}$ of subsidence at BL. 

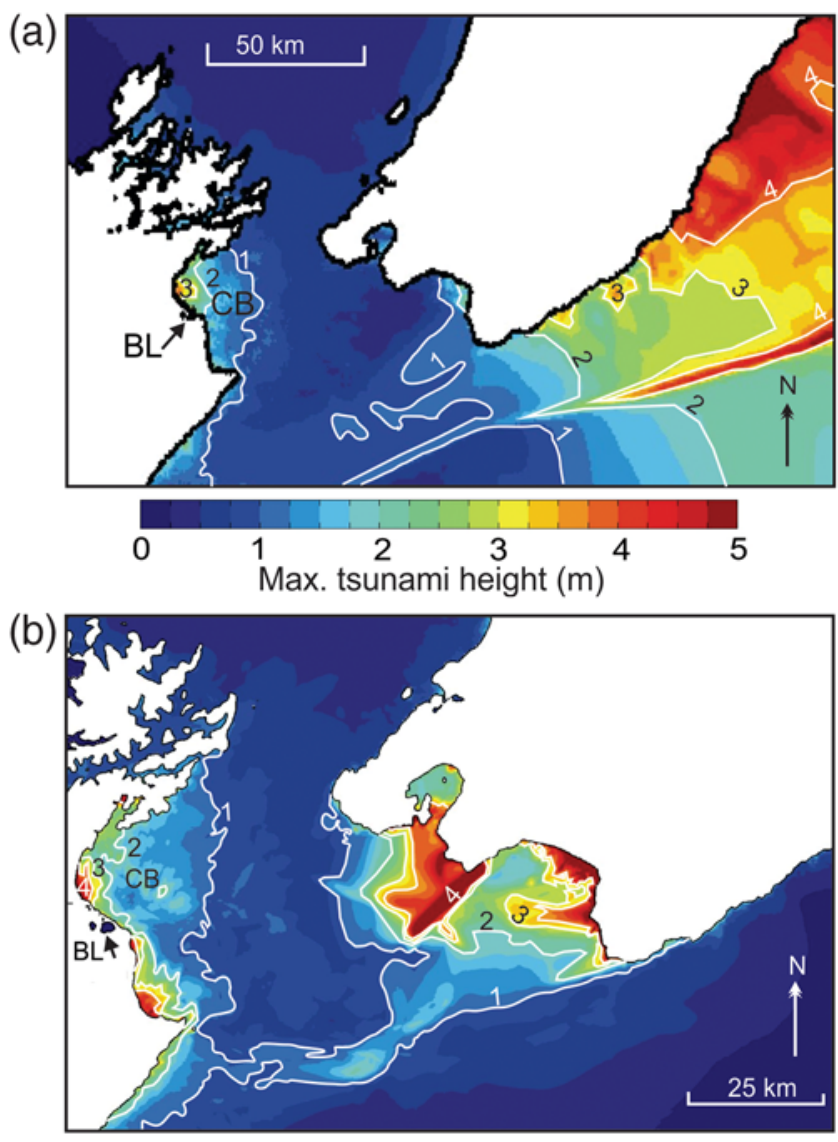

Figure 15. (a) Model of a tsunami generated by a subduction earthquake $\left(M_{\mathrm{w}} 8.8\right)$ along the southern and central Hikurangi margin ( $0-5 \mathrm{~m}$ maximum tsunami height scale). The color scale shows the maximum increase in water level above the background level. White contours show meter gradations in tsunami height. BL, Big Lagoon; CB, Cloudy Bay. The tsunami source model is the same as that modeled in Figure 14b. (b) Model of the tsunami generated by the Wairarapa fault and Wharekahau thrust in the A.D. 1855 $M_{\mathrm{w}} \sim 8.2$ earthquake, showing only a small tsunami height $(<3 \mathrm{~m})$ at Big Lagoon but higher tsunami heights in the middle of Cloudy Bay, which is consistent with historical observations. White contours show meter gradations in tsunami height. The tsunami source model was adapted from Power et al. (2008). Tsunami modeling was conducted using COMCOT (Wang and Liu, 2007). The color version of this figure is available only in the electronic edition.

penultimate rupture of the Wellington fault at 930-790 cal B.P. (Langridge et al., 2011) also overlaps with the earthquake 2 age of $880-800$ cal B.P. However, rupture of the Wellington fault is highly unlikely to cause tectonic subsidence of Big Lagoon because it is dominantly strike slip and does not appear to extend far into Cook Strait. Earthquake 2 (and earthquake 1) also correlates to a very poorly constrained age for beach ridge uplift at the Rongotai isthmus (which may be a result of Wairarapa fault uplift as well; Pillans and Huber, 1995).

The penultimate rupture of the Wairarapa fault at 920800 cal B.P. (Little et al., 2009) correlates in time with earthquake 2 (Fig. 13). The Wairapapa fault is a reverse dextral fault listric to the plate interface. A critical question is whether rupture of the Wairapapa fault on its own could cause tectonic subsidence and tsunami inundation at Big Lagoon or whether the Wairarapa fault could have ruptured synchronously with (or within a few years of) the subduction interface. Great subduction earthquakes have been known to trigger rupture of upper plate faults (Plafker, 1967; Melnick, Moreno et al., 2012), so a scenario involving the plate interface and Wairarapa fault is feasible. Furthermore, there is a possible precedent in the A.D. $1855 M_{\mathrm{w}} 8.2$ Wairarapa earthquake that may have ruptured the deep portion of the plate interface as outlined below.

The A.D. 1855 Wairarapa earthquake caused subsidence of the lower Wairau Valley (including Big Lagoon) and triggered a tsunami 4-5 m high in the middle of Cloudy Bay (Grapes and Downes, 1997). Previous work using elastic dislocation models concluded that tectonic subsidence in the lower Wairau Valley was possible only if the deep portion of the plate interface $(18-30 \mathrm{~km})$ ruptured with the Wairarapa fault (Darby and Beanland, 1992; Beavan and Darby, 2005). A recent study shows the Wairarapa fault intersects the plate interface at $32 \mathrm{~km}$ depth (Henrys et al., 2013), not 18-25 km as previously modeled by Beavan and Darby (2005). Our dislocation models based on the revised geometry of the Wairarapa fault suggest only minor $(<0.2 \mathrm{~m})$ subsidence is likely at Big Lagoon for an earthquake of similar magnitude to the 1855 earthquake that ruptures the full depth of the Wairarapa fault. We suggest the Wairarapa fault alone is unlikely to have caused the $0.5 \mathrm{~m}$ of subsidence observed at Big Lagoon in earthquake 2, but rupture of the Wairarapa fault and the plate interface synchronously (or within a few years of each other) is a possible scenario.

Earthquake 2 probably had different source characteristics from the A.D. 1855 earthquake for the following reasons: (1) earthquake 2 caused greater tectonic subsidence at Big Lagoon than the A.D. 1855 earthquake $(0.45 \pm 0.1 \mathrm{~m}$ in earthquake 2, compared to $\leq 0.3 \mathrm{~m}$ of possible tectonic subsidence, if buried lithofacies $G(p)$ represents A.D. 1855 tectonic subsidence). (2) The tsunami associated with earthquake 2 appears to be larger than the A.D. 1855 tsunami. At our study site in the southeastern corner of Big Lagoon, there is sedimentary evidence of a tsunami with earthquake 2 but no evidence of the A.D. 1855 tsunami, although it was observed to be $\sim 4.3 \mathrm{~m}$ in height just $7 \mathrm{~km}$ further northwest at the tip of the Wairau Bar (Garin, 1855). A tsunami model simulating the A.D. 1855 earthquake (Fig. 15b) shows small tsunami heights $(<3 \mathrm{~m})$ at Big Lagoon but higher tsunami heights in the middle of Cloudy Bay, consistent with historic observations. Sedimentary evidence of the earthquake 2 tsunami has been preserved at the Big Lagoon salt marshes, suggesting the tsunami was larger than the A.D. 1855 tsunami. However, we acknowledge that the direction of tsunami inundation, tide level, sediment availability, or barrier elevation could have been different between the events, and each of these factors may have influenced the deposition and preservation of tsunami deposits. (3) The penultimate Wairapapa fault earthquake was 
probably of a lesser magnitude than A.D. 1855. It had a lesser amount of surface dextral slip (14 m versus $16 \mathrm{~m}$; Rodgers and Little, 2006) and did not produce an uplifted beach ridge at Turakirae Head (Fig. 13; McSaveney et al., 2006; Little et al., 2009).

In summary, the magnitude of paleoenvironmental change and preservation of a tsunami deposit suggest earthquake 2 was associated with more substantial slip on the subduction interface than might have occurred in the A.D. 1855 Wairarapa earthquake (if A.D. 1855 ruptured the plate interface at all). Either earthquake 2 was a subduction earthquake that occurred close in time, but in a separate event, from the penultimate Wairapapa fault earthquake, or the plate interface and Wairarapa fault ruptured synchronously.

\section{Earthquake 1}

The timing of earthquake 1 does not coincide with the timing of any known paleoearthquakes on the upper plate fault in the Cook Strait region, including the nearby Vernon fault (Fig. 13) The lack of correlation of earthquake 1 to paleoearthquakes on the nearby upper plate fault is consistent with the tectonic subsidence arising from rupture of the subduction interface (Fig. 13). The relatively small amount of subsidence that occurred in earthquake $1(0.25 \mathrm{~m})$ may reflect the short-time interval (420-280 yrs) between earthquakes 1 and 2; however such slip predictable behavior may not be typical of subduction interface earthquakes (e.g., Cisternas et al., 2005; Sieh et al., 2008).

Although a paleotsunami deposit was not found associated with earthquake 1 at our Big Lagoon study site, paleotsunami deposits have been described at many locations near and around Cook Strait at about the same time as earthquake 1. These include deposits at Abel Tasman $(120 \mathrm{~km}$ northwest of Big Lagoon; Fig. 1; Goff and Chagué-Goff, 1999) and Okupe Lagoon on Kapiti Island (Fig. 13; Goff et al., 2000; Cochran et al., 2007). Tentative correlations to these widespread paleotsunami deposits suggest earthquake 1 may have caused a significant tsunami that was not preserved at or did not impact our study site in Big Lagoon. Many paleotsunami deposits have been ascribed to a fifteenth-century earthquake or series of earthquakes, although in many cases the age constraints are poor (Goff and McFadgen, 2002; Goff et al., 2004; McFadgen, 2007). A possible correlative recorded in Maori oral history is the Hao-whenua earthquake, estimated to have occurred in the mid-fifteenth century (Best, 1918). The oral history describes uplift in the Wellington region, and King et al. (2007) suggests the name, which translates to "land-swallower," may imply an associated tsunami. The scenario presented here of a southern Hikurangi margin subduction interface earthquake at A.D. 1430-1480 (520-470 cal B.P.) is a plausible cause for the ubiquitous fifteenth-century paleostunami deposits, may correlate with the Hao-whenua earthquake, and may also account for other landscape change features observed by Goff and McFadgen (2002), such as landslides, river aggradation, coastal dune building, and archaeological site abandonment.

At this stage, the likelihood of earthquake 1 being a subduction interface rupture is based largely upon the lack of correlation to ruptures of nearby upper plate faults and possible correlations with a regional paleotsunami deposits. However, it is acknowledged that a paleoearthquake may not yet have been discovered on a known or currently unknown upper plate fault in the region, therefore there remains a possibility that earthquake 1 is related to an earthquake on an upper plate fault. Given the evidence thus far, our preferred explanation is that it was a subduction interface rupture, but ongoing studies are focusing on correlating earthquake 1 to other sites of coastal deformation and paleotsunami deposition on the southern Hikurangi margin with the goal of better constraining the seismic source.

\section{Discussion}

\section{Along-Margin Correlation}

Correlation of earthquake impacts between widely spaced sites can help estimate the extent of past earthquake rupture (e.g., Nelson et al., 2006; Goldfinger et al., 2012; Shennan, Bruhn, et al., 2014). Furthermore, in the case of subduction margins with pervasive upper plate faults, correlation between sites at greater distances apart than the length of upper plate faults can also help to distinguish between upper plate fault rupture and plate interface rupture, although clustering of earthquakes on upper plate faults is also feasible. When using geologic data it is often impossible to determine whether two earthquake impacts occurred at exactly the same time because of the age range uncertainties produced by radiocarbon dating. Frequently, a high degree of age overlap between sites is evidence that deformation at the two sites could have occurred synchronously in the same earthquake, but usually a series of lesser magnitude events closely spaced in time cannot be ruled out (e.g., Nelson et al., 2006).

At coastal sites along the Hikurangi margin, as many as seven paleoearthquakes have been identified dating back to 7000 yrs B.P. (Fig. 16; see figure caption for data references). The paleoearthquake records have been derived from coastal subsidence and paleotsunami records and from marine terraces; some of the earthquakes probably represent subduction interface ruptures, whereas others are related to upper plate faults. A turbidite record has also been obtained from offshore northern Hikurangi margin, although the record probably contains a mixture of upper plate fault and subduction earthquake triggered turbidites (Pouderoux et al., 2014). Figure 16, adapted from Wallace et al. (2014), has been updated with the new earthquake ages from Big Lagoon. At half of these sites (Turakirae Head, south Wairarapa coast, Mahia, and Pakarae), paleoearthquake evidence consists of marine terraces, uplift of which has previously been attributed to active nearshore, listric reverse faults (Berryman, 1993; McSaveney, Graham et al., 2006; Wilson et al., 

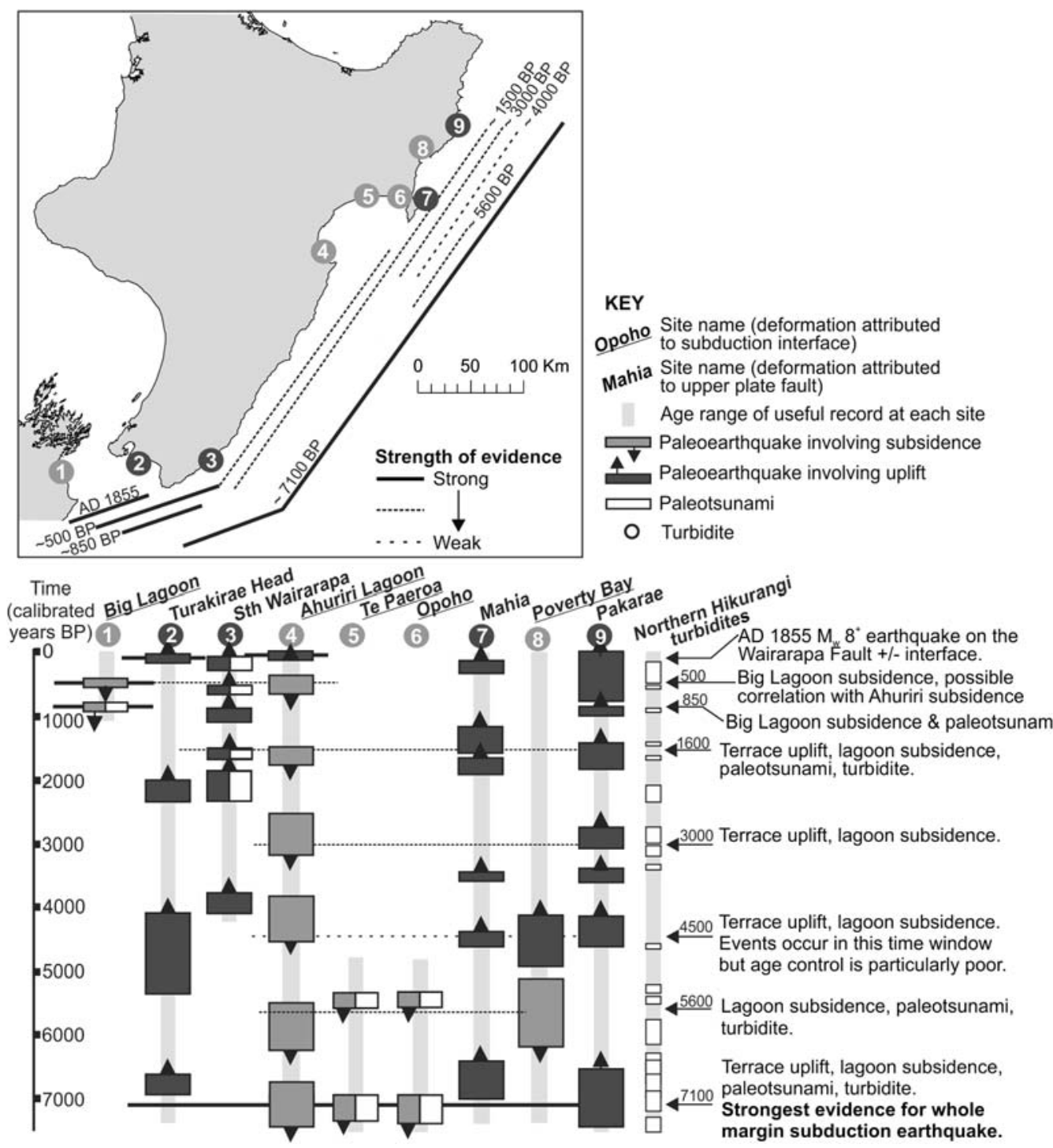

Figure 16. A compilation of upper plate coastal deformation data from along the Hikurangi margin, figure adapted from Wallace et al. (2014) and updated with the earthquake ages from this study of Big Lagoon and with the northern Hikurangi turbidite record (Pouderoux et al., 2014). The upper map shows the study locations and possible rupture lengths for past subduction earthquakes. The lower graph shows the age of coastal uplift, subsidence, and paleotsunami events along the margin and tentative correlations between the events. The marine terrace uplift at Turakirae Head, south Wairarapa coast, Mahia, and Pakarae has previously been interpreted as related to offshore reverse faults and the turbidite record probably contains a mixture of upper plate fault and subduction earthquakes (Pouderoux et al., 2014). Data sources: site 2, McSaveney et al. (2006); site 3, Berryman et al. (2011); site 4, Hayward et al. (2006); sites 5 and 6, Cochran et al. (2006); site 7, Berryman (1993); site 8, Hayward et al. (2015); and site 9, Wilson et al. (2006).

2006; Litchfield, Wilson, et al., 2010; Berryman et al., 2011). We include these data in Figure 16 because subduction interface rupture could conceivably have triggered synchronous rupture of the upper plate faults responsible for terrace uplift, or uplift due to slip on the subduction interface could be preserved in the marine terrace record.

The timing of earthquake 2 (880-800 cal B.P.) does not correlate with subduction earthquake evidence elsewhere along the Hikurangi margin. The inferred interface rupture in earthquake 2 may have been confined to rupture of the southern Hikurangi margin, although it is also possible that evidence for this event has not yet been discovered on the rest of the margin.
The timing of earthquake 1 (520-470 cal B.P.) is similar to the timing of the most recent subsidence event at Ahuriri Lagoon and a turbidite on the northern Hikurangi margin (Fig. 16). High-resolution dating of the youngest south Wairarapa coast marine terrace has shown it was uplifted at 655-615 cal B.P. (Litchfield et al., 2013) and therefore has no age overlap with earthquake 1 at Big Lagoon (Fig. 16). The most recent coseismic subsidence at Ahuriri Lagoon was estimated at 500 yrs B.P. by Hull (1986) and $600 \mathrm{cal}$ B.P. by Hayward et al. (2006), although the actual radiocarbon constraints show the event probably occurred just prior to $630-340$ cal B.P. Therefore, the most 
recent coseismic subsidence at Ahuriri is compatible with a correlation to earthquake 1 (Fig. 16), but higher precision age control at Ahuriri is required to have greater confidence in the possible correlation. Earthquake 1 also correlates with a turbidite deposit offshore of the northern Hikurangi margin (Fig. 16) dated at 555-215 cal B.P. (Pouderoux et al., 2014). The wide age range on the turbidite deposit means it also overlaps with upper plate fault ruptures on the northern margin that uplifted marine terraces at Pakarae and Mahia Peninsula. As with Ahuriri, more precise age control on the turbidite would be necessary before a confident correlation with earthquake 1 was made.

\section{Implications for Seismic Hazard}

It has long been assumed that the southern Hikurangi subduction interface is capable of generating large to great subduction earthquakes and will do so in the future (e.g., Wallace et al., 2009; Stirling et al., 2012), but such assumptions were made largely on the basis of a zone of contemporary interseismic locking beneath the southern Hikurangi margin (Reyners, 1998; Wallace et al., 2004). This study is the first to provide geological evidence of large to great subduction earthquakes on the southern Hikurangi margin interface. If, as we interpret them, both earthquakes 1 and 2 at Big Lagoon represent subduction earthquakes, then the relatively short-time interval between earthquakes 1 and 2 suggests the recurrence interval could be shorter than previously estimated.

The interval between earthquakes 1 and 2 is $~ 350$ yrs, but it may be as long as $405 \mathrm{yrs}$ and as short as $280 \mathrm{yrs}$. The most recent review of the New Zealand National Seismic Hazard Model (Stirling et al., 2012) did not use any paleoseismological constraints in its estimation of Hikurangi subduction interface earthquake rupture areas, earthquake magnitude, or recurrence interval; these parameters were based largely on historical seismicity and the distribution of interseismic coupling. For the southern Hikurangi earthquake source model, rupture scenarios involving slip from (a) $15-25 \mathrm{~km}$ and (b) 5-30 km depth on the plate interface produced events of $M_{\mathrm{w}} 8.1-8.4$ at recurrence intervals of 550-1000 yrs. Although we acknowledge that significantly more than two paleoearthquakes are needed to calculate a reliable average recurrence interval, we note that, at present, the National Seismic Hazard Model recurrence estimates of $550-1000$ yrs do not reconcile with the $\sim 350 \mathrm{yr}$ interevent time documented in this study.

The National Seismic Hazard Model includes earthquake sources for the southern, central, and northern Hikurangi margin, along with an $M_{\mathrm{w}} 9.0$ source model spanning all three segments (Stirling et al., 2012). Our tentative correlations between earthquake 1 and the $\sim 600 \mathrm{yr}$ B.P. Ahuriri subsidence event does not definitively confirm a whole margin rupture, but it does suggest that an earthquake source incorporating the southern and central Hikurangi margin is realistic and should be considered in future seismic-hazard models.
The apparent differences between our study and the National Seismic Hazard Model highlights the need to conduct more detailed investigations of paleoearthquakes to better refine our understanding of the size and recurrence of Hikurangi margin subduction interface earthquakes. The consequences of a large to great subduction earthquake on the Hikurangi margin are likely to be severe. For an $M_{\mathrm{w}} 8.9$ Hikurangi sudduction interface earthquake (a scenario based on the National Seismic Hazard Model, Stirling et al., 2012), losses in the Wellington region alone are estimated to be $\sim 13$ billion, with $\sim 3550$ deaths and $\sim 7000$ injuries (Cousins, 2013). Refined knowledge of the size and subduction interface earthquakes, their along-margin extent, and size of triggered tsunami will allow more precise modeling of the impacts and assist in preparing communities to be more resilient to such events.

\section{Conclusions}

Salt marsh stratigraphy at Big Lagoon shows evidence for two sudden subsidence events that we attribute to subduction earthquakes on the southern Hikurangi margin. Both earthquakes are expressed by paleosols overlain by silty clay or tsunami sand. Despite low abundances, foraminiferal assemblages demonstrate the paleosol-clay contacts are associated with paleoelevation changes: $\sim 0.45 \mathrm{~m}$ of subsidence in earthquake 2 and $\sim 0.25 \mathrm{~m}$ in earthquake 1 . The paleosol of earthquake 2 is also overlain by tsunami sand containing foraminifera from a wide range of offshore and landward habitats. Using age constraints provided by radiocarbon dating, we estimate that earthquake 2 occurred at $880-800 \mathrm{cal}$ B.P. and earthquake 1 occurred at 520-470 cal B.P.

Coseismic subsidence of Big Lagoon is consistent with the upper plate vertical deformation expected from rupture of the subduction interface. Earthquake 2 correlates in age with the penultimate rupture of the Wairarapa fault, but the amount of subsidence recorded at Big Lagoon exceeds that which potentially occurred in the A.D. 1855 Wairarapa fault rupture. We suggest the primary cause of earthquake 2 was rupture of the subduction interface with possible synchronous upper plate faulting. Earthquake 1 has no upper plate earthquake correlatives, and we suggest it was caused by rupture of the plate interface alone.

This study presents the first geological evidence of past large subduction earthquakes on the southern Hikurangi subduction interface and confirms that this segment of the margin is prone to rupture in large to great earthquakes-an assumption that was previously only based on seismic and geodetic evidence of strong contemporary plate coupling. The relatively short time interval between the two earthquakes of $\sim 350$ yrs is currently shorter than the recurrence interval for the southern segment in the New Zealand National Seismic Hazard Model. Correlation to records of subduction earthquake deformation elsewhere along the Hikurangi margin is an ongoing work. Higher precision ages for recent coseismic subsidence events on the central margin 
and filling in geographic gaps should help to understand the rupture segmentation of the margin.

Analogous settings to the southern Hikurangi margin (i.e., where active upper plate faults are prevalent in areas where subduction earthquake evidence is sought) can occur at transitional plate boundaries and when subduction of buoyant masses such as seamounts and plateaus produce intense upper plate deformation. Our study demonstrates that along complex plate margins, geological evidence of subduction earthquakes can be isolated if the effects of upper plate faults can be taken into account.

\section{Data and Resources}

The onshore active fault maps used in Figures 1 and 13 were from the New Zealand Active Faults Database (http:// data.gns.cri.nz/af/; last accessed May 2014). Historical accounts of the tsunami generated by the A.D. 1855 Wairarapa earthquake were obtained from the New Zealand Tsunami Database: Historical and Modern Records, compiled by Gaye Downes (http://data.gns.cri.nz/tsunami/index.html; last accessed July 2014). Historic earthquakes were searched for in the Geonet Earthquake Catalogue (http://info.geonet. org.nz/display/appdata/Earthquake+Resources; last accessed September 2014).

\section{Acknowledgments}

This research was funded by the GNS core-funded Tectonics and Structure of Zealandia Programme, the "It's Our Fault" project, an EQC Biennial Project grant to GNS Science, and by New Zealand Natural Hazards Research Platform and Foundation for Research Science and Technology grants to Geomarine Research. Finn Scheele and Mike Rosenberg obtained the grain size data; we particularly thank Mike Rosenberg for his advice. We thank Paul Leedom and Leigh Maddison for facilitating access to Big Lagoon, the Department of Conservation for allowing access to the salt marshes, and Hugh Grenfell, Jamie Howarth, Nicola Litchfield, William Ries, and Delia Strong for field work assistance. Light Detection and Ranging (LiDAR) imagery of Big Lagoon was kindly provided by Marlborough District Council. This article was improved by reviews by Nicola Litchfield, Andy Nicol, Tina Dura, Associate Editor Brian Sherrod, and an anonymous reviewer.

\section{References}

Atwater, B. F. (1987). Evidence for great Holocene earthquakes along the outer coast of Washington State, Science 236, 942-944.

Barnes, P. M., and B. Mercier de Lepinay (1997). Rates and mechanics of rapid frontal accretion along the very obliquely convergent southern Hikurangi margin, New Zealand, J. Geophys. Res. 102, no. B11, 24,931-24,952.

Barnes, P. M., and N. Pondard (2010). Derivation of direct on-fault submarine paleoearthquake records from high-resolution seismic reflection profiles: Wairau fault, New Zealand, Geochem. Geophys. Geosyst. 11, no. 11, Q11013, doi: 10.1029/2010GC003254.

Barnes, P. M., B. Mercier de Lepinay, J.-Y. Collot, J. Delteil, and J.-C. Audru (1998). Strain partitioning in the transition area between oblique subduction and continental collision, Hikurangi margin, New Zealand, Tectonics 17, no. 4, 534-557.

Bartholomew, T. D., T. A. Little, K. J. Clark, R. Van Dissen, and P. M. Barnes (2014). Kinematics and paleoseismology of the Vernon fault, Marlborough fault system, New Zealand: Implications for contractio- nal fault bend deformation, earthquake triggering, and the record of Hikurangi subduction earthquakes, Tectonics 33, no. 7, 1201-1218, TC003543, doi: 10.1002/2014TC003543.

Beavan, J., and D. Darby (2005). Fault slip in the 1855 Wairarapa earthquake based on new and reassessed vertical motion observations: Did slip occur on the subduction interface? Proceedings of the 1855 Wairarapa Earthquake Symposium, Museum of New Zealand Te Papa Tongarewa, Wellington, New Zealand, 8-10 September 2005, Volume GW/RINV-T-05/205, Greater Wellington Regional Council, 31-41.

Berryman, K. R. (1993). Age, height, and deformation of Holocene terraces at Mahia Peninsula, Hikurangi subduction margin, New Zealand, Tectonics 12, no. 6, 1347-1364.

Berryman, K., Y. Ota, T. Miyauchi, A. Hull, K. Clark, K. Ishibashi, N. Iso, and N. Litchfield (2011). Holocene paleoseismic history of upper-plate faults in the southern Hikurangi subduction margin, New Zealand, deduced from marine terrace records, Bull. Seismol. Soc. Am. 101, no. 5, 2064-2087.

Best, E. (1918). The Land of Tara and they who settled it. Part III, Transaction Proceedings of the Polynesian Society 27, 49-71.

Bronk Ramsey, C. (2009). Bayesian analysis of radiocarbon dates, Radiocarbon 51, no. 1, 337-360.

Brown, L. J. (1981). Late Quaternary geology of the Wairau Plain, Marlborough, New Zealand, New Zeal. J. Geol. Geophys. 24, 477-490.

Cisternas, M., B. Atwater, F. Torrejon, Y. Sawai, G. Machuca, M. Lagos, A. Eipert, C. Toulton, I. Saldago, T. Kamataki, et al. (2005). Predecessors of the giant 1960 Chile earthquake, Nature 437, 404-407.

Clark, K. J., B. Hayward, U. Cochran, H. R. Grenfell, E. Hemphill-Haley, D. Mildenhall, M. Hemphill-Haley, and L. Wallace (2011). Investigating subduction earthquake geology along the southern Hikurangi margin using paleoenvironmental histories of intertidal inlets, New Zeal. J. Geol. Geophys. 54, no. 3, 255-271.

Clark, K. J., R. Van Dissen, N. Litchfield, T. Bartholomew, and T. Little (2011). The Vernon fault: Onshore paleoseismicity, constraints on slip rate, and contribution to Holocene tectonic subsidence of Big Lagoon, GNS Science Report 2011/42, 32 pp.

Cochran, U., K. Berryman, D. Mildenhall, B. Hayward, K. Southall, C. Hollis, P. Barker, L. Wallace, B. Alloway, and K. Wilson (2006). Paleoecological insights into subduction zone earthquake occurrence, eastern North Island, New Zealand, Geol. Soc. Am. Bull. 118, nos. 9/ 10, 1051-1074.

Cochran, U. A., M. Hannah, M. A. Harper, R. Van Dissen, K. Berryman, and J. Begg (2007). Detection of large, Holocene earthquakes using diatom analysis of coastal sedimentary sequences, Wellington, New Zealand, Quaternary Sci. Rev. 26, nos. 7/8, 1129-1147.

Cousins, J. W. (2013). Earthquake damage and casualties due to large earthquakes impacting Wellington region, GNS Science Report 2013-41, $12 \mathrm{pp}$.

Darby, D., and S. Beanland (1992). Possible source models for the 1855 Wairarapa earthquake, New Zealand, J. Geophys. Res. 97, 12,37512,389 .

Denys, L. (1988). Fragilaria blooms in the Holocene of the western coastal plain of Belgia, in H. Simola (Editor), Proc. of the 10th International Diatom Symposium, Joensun, Finland, 28 August-2 September 1988, 397-406.

Dominey-Howes, D. T. M., G. S. Humphreys, and P. P. Hesse (2006). Tsunami and palaeotsunami depositional signatures and their potential value in understanding the late-Holocene tsunami record, Holocene 16, no. 8, 1095-1107.

Doser, D. I., and T. H. Webb (2003). Source parameters of large historical (1917-1961) earthquakes, North Island, New Zealand, Geophys. J. Int. 152, 795-832.

Figueira, B. O. (2012). Salt marsh proxy record of late Holocene sea-level rise, South Island, New Zealand, Ph.D. Thesis, University of Auckland, New Zealand, 205 pp.

Garin, A. (1855). Mission Notes, Marist Fathers Archive, Rome, Translated by P. Tremewan, University of Canterbury, Christchurch, New Zealand, 2000-2001. 
Gehrels, R., B. Hayward, R. Newnham, and K. Southall (2008). A 20th century acceleration of sea-level rise in New Zealand, Geophys. Res. Lett. 35, LO2717, doi: 10.1029/2007GL032632.

Goff, J. R., and C. Chagué-Goff (1999). A late Holocene record of environmental changes from coastal wetlands: Abel Tasman National Park, New Zealand, Quaternary Int. 56, no. 1, 39-51.

Goff, J. R., and B. G. McFadgen (2002). Seismic driving of nationwide changes in geomorphology and prehistoric settlement-A 15th century New Zealand example, Quaternary Sci. Rev. 21, 2229-2236.

Goff, J., C. Chagué-Goff, S. Nichol, B. Jaffe, and D. Dominey-Howes (2012). Progress in palaeotsunami research, Sediment. Geol. 243/ 244, 70-88.

Goff, J. R., B. G. McFadgen, and C. Chague-Goff (2004). Sedimentary differences between the 2002 Easter storm and the 15th-century Okoropunga tsunami, southeastern North Island, New Zealand, Mar. Geol. 204, 235-250.

Goff, J. R., H. L. Rouse, S. L. Jones, B. W. Hayward, U. Cochran, W. McLea, W. W. Dickinson, and M. S. Morley (2000). Evidence for an earthquake and tsunami about 3100-3400 yr ago, and other catastrophic slatwater inundations in a coastal lagoon, New Zealand, Mar. Geol. 170, 231-249.

Goldfinger, C., C. H. Nelson, A. Morey, J. E. Johnson, J. Gutierrez-Pastor, A. T. Eriksson, E. Karabanov, J. Patton, E. Gracia, R. Enkin, et al. (2012). Turbidite event history: Methods and implications for Holocene paleoseismicity of the Cascadia subduction zone, U.S. Geol. Surv. Profess. Pap. 1661-F, 170 pp.

Grapes, R. (1989). The Wairarapa fault: Displacements and paleoseismicity, Bull. New Zeal. Natl. Soc. Earthq. Eng. 22, no. 1, 13-16.

Grapes, R., and G. Downes (1997). The 1855 Wairarapa, New Zealand, earthquake-Analysis of historical data, Bull. New Zeal. Natl. Soc. Earthq. Eng. 30, 271-368.

Grenfell, H. R., B. W. Hayward, R. Nomura, and A. T. Sabaa (2012). Proxy record of 20th century sea-level rise in the Manukau Harbour, New Zealand, Mar. Freshwat. Res. 63, 370-384.

Gulick, S. P. S., L. A. Lowe, T. L. Pavlis, J. V. Gardner, and L. A. Mayer (2007). Geophysical insights into the Transition fault debate: Propagating strike slip in response to stalling Yakutat block subduction in the Gulf of Alaska, Geology 35, no. 8, 763-766.

Hartley, B. (1996). An Atlas of British Diatoms, Biopress Ltd., Bristol, England.

Hawkes, A. D., M. Bird, S. Cowie, C. Grundy-Warr, B. P. Horton, A. T. Shau Hwai, L. Law, C. Macgregor, J. Nott, J. E. Ong, et al. (2007). Sediments deposited by the 2004 Indian Ocean tsunami along the Malaysia-Thailand peninsula, Mar. Geol. 242, nos. 1/3, 169-190.

Hayward, B. W., and C. J. Hollis (1994). Brackish foraminifera in New Zealand: A taxonomic and ecologic review, Micropaleontology 40, $185-222$.

Hayward, B. W., H. R. Grenfell, C. Reid, and K. Hayward (1999). Recent New Zealand shallow-water benthic foraminifera: Taxonomy, ecologic distribution, biogeography, and use in paleoenvironmental assessment, Institute of Geological and Nuclear Sciences Monograph 21, Institute of Geological and Nuclear Sciences Limited, Lower Hutt, New Zealand, $264 \mathrm{pp}$.

Hayward, B. W., H. R. Grenfell, and A. T. Sabaa (2012). Marine submersion of an archaic moa-hunter occupational site, Shag River estuary, North Otago, New Zeal. J. Geol. Geophys. 55, no. 2, 127-136.

Hayward, B. W., H. R. Grenfell, A. Sabaa, R. Carter, U. Cochran, J. H. Lipps, P. Shane, and M. S. Morley (2006). Micropaleontological evidence of large earthquakes in the past 7200 years in southern Hawke's Bay, New Zealand, Quaternary Sci. Rev. 25, nos. 11/12, $1186-1207$.

Hayward, B. W., H. R. Grenfell, A. T. Sabaa, and K. Clark (2012). Foraminiferal evidence for Holocene synclinal folding at Porangahau, southern Hawkes Bay, New Zealand, New Zeal. J. Geol. Geophys. 55, no. 1, 21-35.

Hayward, B. W., H. R. Grenfell, A. T. Sabaa, and J. Kay (2010). Using foraminiferal faunas as proxies for low tide level in the estimation of Holocene tectonic subsidence close to the Pacific-Australian plate boundary, New Zealand, Mar. Micropaleontol. 76, 23-36.

Hayward, B. W., H. R. Grenfell, A. T. Sabaa, J. Kay, and K. Clark (2011). Ecological distribution of the foraminifera in a tidal lagoon-brackish lake, New Zealand, and its Holocene origins, J. Foraminiferal Res. 41, no. $2,124-137$.

Hayward, B., H. R. Grenfell, A. Sabaa, J. Kay, R. Daymond-King, and U. Cochran (2010). Holocene subsidence at the transition between strikeslip and subduction on the Pacific-Australian plate boundary, Marlborough Sounds, New Zealand, Quaternary Sci. Rev. 29, 648-661.

Hayward, B. W., H. R. Grenfell, and D. B. Scott (1999). Tidal range of marsh foraminifera for determining former sea-level heights in New Zealand, New Zeal. J. Geol. Geophys. 42, 395-413.

Hayward, B. W., C. J. Hollis, and H. R. Grenfell (1997). Recent Elphidiidae (Foraminiferida) of the South-west Pacific and fossil Elphidiidae of New Zealand, Institute of Geological and Nuclear Sciences Monograph 16, Institute of Geological and Nuclear Sciences Limited, Lower Hutt, New Zealand, 170 pp.

Hayward, B. W. H., A. Sabaa, H. R. Grenfell, U. Cochran, K. J. Clark, N. J. Litchfield, L. Wallace, M. Marden, and A. Palmer (2015). Foraminiferal record of Holocene paleoearthquakes on the subsiding southwestern Poverty Bay coastline, New Zealand, New Zeal. J. Geol. Geophys., doi: 10.1080/00288306.2014.992354.

Hayward, B. W., G. H. Scott, H. R. Grenfell, R. Carter, and J. H. Lipps (2004). Techniques for estimation of tidal elevation and confinement ( $\sim$ salinity) histories of sheltered harbours and estuaries using benthic foraminifera: Examples from New Zealand, Holocene 14, no. 2, 218-232.

Hayward, B., K. J. Wilson, M. Morley, U. Cochran, H. R. Grenfell, A. Sabaa, and R. Daymond-King (2010). Microfossil record of the Holocene evolution of coastal wetlands in a tectonically active region of New Zealand, Holocene 30, no. 3, 405-421.

Henrys, S., A. Wech, R. Sutherland, T. Stern, M. Savage, H. Sato, K. Mochizuki, T. Iwasaki, D. Okaya, A. Seward, et al. (2013). SAHKE geophysical transect reveals crustal and subduction zone structure at the southern Hikurangi margin, New Zealand, Geochem. Geophys. Geosyst. 14, no. 7, 2063-2083.

Hogg, A. G., Q. Hua, P. G. Blackwell, M. Niu, C. E. Buck, T. P. Guilderson, T. J. Heaton, J. G. Palmer, P. J. Reimer, R. W. Reimer, et al. (2013). SHCal13 Southern Hemisphere Calibration, 0-50,000 Years cal B.P., Radiocarbon 55, no. 4, 1889-1903.

Holden, C., A. E. Kaiser, R. Van Dissen, and R. Jury (2013). Sources, ground motion and structural response characteristics in Wellington of the 2013 Cook Strait earthquakes, Bull. New Zeal. Soc. Earthq. Eng. 46, no. 4, 188-195.

Hull, A. G. (1986). Pre-A.D. 1931 tectonic subsidence of Ahuriri Lagoon, Napier, Hawkes Bay, New Zealand, New Zeal. J. Geol. Geophys. 29, 75-82.

Hull, A. G. (1990). Tectonics of the 1931 Hawke's Bay earthquake, New Zeal. J. Geol. Geophys. 33, 309-320.

Kelsey, H. M., A. R. Nelson, E. Hemphill-Haley, and R. C. Witter (2005). Tsunami history of an Oregon coastal lake reveals a $4600 \mathrm{yr}$ record of great earthquakes on the Cascadia subduction zone, Geol. Soc. Am. Bull. 117, nos. 7/8, 1009-1032.

King, D. N. T., J. Goff, and A. Skipper (2007). Maori environmental knowledge and natural hazards in Aotearoa-New Zealand, J. Roy. Soc. New Zeal. 37, no. 2, 59-73.

Krammer, K., and H. Lange-Bertalot (1991). Bacillariophyceae: Achnanthaceae, Gustav Fischer Verlag, Stuttgart, Germany.

Krammer, K., and H. Lange-Bertalot (1999a). Bacillariophyceae: Bacillariaceae, Epithemiaceae, Surirellaceae, Specktrum Akademischer Verlag, Heidelberg, Germany.

Krammer, K., and H. Lange-Bertalot (1999b). Bacillariophyceae: Naviculaceae, Specktrum Akademischer Verlag, Heidelberg, Germany.

Krammer, K., and H. Lange-Bertalot (2000). Bacillariophyceae: Centrales, Fragilariaceae, Eunotiaceae, Spektrum Akademischer Verlag, Heidelberg, Germany.

Langridge, R., R. Van Dissen, D. Rhoades, P. Villamor, T. Little, N. Litchfield, K. Clark, and D. Clark (2011). Five thousand years of surface 
ruptures on the Wellington fault, New Zealand: Implications for recurrence and fault segmentation, Bull. Seismol. Soc. Am. 101, no. 5, 2088-2107.

Lienkaemper, J. J., and C. Bronk Ramsey (2009). OxCal: Versatile tool for developing paleoearthquake chronologiesüA primer, Seismol. Res. Lett. 80, no. 3, 431-434.

Litchfield, N. J., U. A. Cochran, K. R. Berryman, B. Ansell, and K. Clark (2013). Timing and amount of uplift of the youngest Holocene marine terrace along the Honeycomb Rock-Riversdale Beach coast, eastern Wairarapa, GNS Science Report 2013/54, 44 pp.

Litchfield, N., R. Van Dissen, M. Hemphill-Haley, D. Townsend, and D. Heron (2010). Post c. 300 year rupture of the Ohariu fault in Ohariu Valley, New Zealand, New Zeal. J. Geol. Geophys. 53, no. 1, 43-56.

Litchfield, N., R. Van Dissen, D. Heron, and D. Rhoades (2006). Constraints on the timing of the three most recent surface rupture events and recurrence interval for the Ohariu fault: Trenching results from MacKays Crossing, Wellington, New Zealand, New Zeal. J. Geol. Geophys. 49, no. 1, 57-61.

Litchfield, N., R. Van Dissen, R. Langridge, D. Heron, and C. Prentice (2004). Timing of the most recent surface rupture event on the Ohariu fault near Paraparaumu, New Zealand, New Zeal. J. Geol. Geophys. 47, no. 1, 123-127.

Litchfield, N. J., R. Van Dissen, R. Sutherland, P. M. Barnes, S. C. Cox, R. Norris, R. J. Beavan, R. Langridge, P. Villamor, K. Berryman, et al. (2014). A model of active faulting in New Zealand, New Zeal. J. Geol. Geophys. 57, no. 1, 32-56.

Litchfield, N., K. Wilson, K. Berryman, and L. Wallace (2010). Coastal uplift mechanisms at Pakarae River mouth: Constraints from a combined Holocene fluvial and marine terrace dataset, Mar. Geol. 270, 72-83.

Little, T. A., R. Van Dissen, E. Schermer, and R. Carne (2009). Late Holocene surface ruptures on the southern Wairarapa fault, New Zealand: Link between earthquakes and the uplifting of beach ridges on a rocky coast, Lithosphere 1, 4-28.

Mason, D. P. M., T. A. Little, and R. J. Van Dissen (2006). Refinements to the paleoseismic chronology of the eastern Awatere fault from trenches near Upcot Saddle, Marlborough, New Zealand, New Zeal. J. Geol. Geophys. 49, no. 3, 383-397.

McFadgen, B. G. (2007). Hostile Shores: Catastrophic Events in Prehistoric New Zealand and Their Impact on Maori Coastal Communities, Auckland University Press, Auckland, New Zealand.

McSaveney, M., I. Graham, J. Begg, A. Beu, A. Hull, K. Kim, and A. Zondervan (2006). Late Holocene uplift of beach ridges at Turakirae Head, south Wellington coast, New Zealand, New Zeal. J. Geol. Geophys. 49, 337-358.

Melnick, D., M. Moreno, M. Motagh, M. Cisternas, and R. L. Wesson (2012). Splay fault slip during the $M_{\mathrm{w}} 8.82010$ Maule Chile earthquake, Geology 40, no. 3, 251-254.

Minoura, K., F. Imamura, D. Sugawara, Y. Kono, and T. Iwashita (2001). The 869 Jogan tsunami deposit and recurrence of large-scale tsunami on the Pacific coast of northeast Japan, J. Nat. Disast. Sci. 23, no. 2, 83-88.

Morton, R. A., G. Gelfenbaum, M. L. Buckley, and B. M. Richmond (2011). Geological effects and implications of the 2010 tsunami along the central coast of Chile, Sediment. Geol. 242, nos. 1/4, 34-51.

Morton, R. A., G. Gelfenbaum, and B. Jaffe (2007). Physical criteria for distinguishing sandy tsunami and storm deposits using modern examples, Sediment. Geol. 200, 184-207.

Nanayama, F., K. Satake, R. Furukawa, K. Shimokawa, B. F. Atwater, K. Shigeno, and S. Yamaki (2003). Unusually large earthquakes inferred from tsunami deposits along the Kuril trench, Nature 424, 660-663.

Nelson, A. R., H. M. Kelsey, and R. C. Witter (2006). Great earthquakes of variable magnitude at the Cascadia subduction zone, Quaternary Res. 65, 354-365.

Nelson, A. R., I. Shennan, and A. J. Long (1996). Identifying coseismic subsidence in tidal-wetland stratigraphic sequences at the Cascadia subduction zone of western North America, J. Geophys. Res. 101, 6115-6135.
Nicol, A., and J. Beavan (2003). Shortening of an overriding plate and its implications for slip on a subduction thrust, central Hikurangi margin, New Zealand, Tectonics 22, no. 6, 1070, doi: 10.1029/2003TC001521.

Nicol, A., R. Langridge, and R. Van Dissen (2011). Wairau fault Late Quaternary displacements and paleoearthquakes, J. M. Lee (Editor), Field Trip Guides, Geosciences 2011 Conference, Geoscience Society of New Zealand Miscellaneous Publication 130B, Nelson, New Zealand, 27 November-1 December 2011, 33 pp.

Ota, Y., L. J. Brown, K. R. Berryman, T. Fujimori, T. Miyauchi, A. G. Beu, K. Kashima, and K. Taguchi (1995). Vertical tectonic movement in northeastern Marlborough: Stratigraphic, radiocarbon, and paleoecological data from Holocene estuaries, New Zeal. J. Geol. Geophys. 38, 269-282.

Peters, R., and B. E. Jaffe (2010). Identification of tsunami deposits in the geologic record: Developing criteria using recent tsunami deposits, U.S. Geol. Surv. Open-File Rept. 2010-1239, 39 pp., http://pubs.usgs.gov/of/ 2010/1239/ (last accessed September 2014).

Pillans, B., and P. Huber (1995). Interpreting coseismic deformation using Holocene coastal deposits, Wellington, New Zealand, Quaternary Int. 26, 87-95.

Plafker, G. (1967). Surface faults on Montague Island associated with the 1964 Alaska earthquake, U.S. Geol. Surv. Profess. Pap. 543-G, 42 pp.

Pondard, N., and P. M. Barnes (2010). Structure and paleoearthquake records of active submarine faults, Cook Strait, New Zealand: Implications for fault interactions, stress loading, and seismic hazard, $J$. Geophys. Res. 115, no. B12, B12320.

Pouderoux, H., J.-N. Proust, and G. Lamarche (2014). Submarine paleoseismology of the northern Hikurangi subduction margin of New Zealand as deduced from turbidite record since $16 \mathrm{ka}$, Quaternary Sci. Rev. 84, 116-131.

Power, W. L. (Compiler) (2013). Review of Tsunami Hazard in New Zealand (2013 Update), GNS Science Consultancy Report 2013/ 131, 222 pp., available at http://www.civildefence.govt.nz/assets/ Uploads/publications/GNS-CR2013-131-Tsunami-Report-Full.pdf (last accessed September 2014).

Power, W. L., M. E. Reyners, and L. W. Wallace (2008). Tsunami hazard posed by earthquakes on the Hikurangi subduction zone interface, GNS Science Consultancy Report 2008/40, 58 pp., available at http://www.eqc.govt .nz/sites/public_files/1600-tsunami-hazard-Hikurangi-subduction-zoneinterface.pdf (last accessed September 2014).

Reimer, P. J., E. Bard, A. Bayliss, J. W. Beck, P. G. Blackwell, C. Bronk Ramsey, P. M. Grootes, T. P. Guilderson, H. Haflidason, I. Hajdas, et al. (2013). IntCal13 and Marine13 radiocarbon age calibration curves 0-50,000 years cal B.P., Radiocarbon 55, no. 4, 1869-1887.

Reyners, M. (1998). Plate coupling and the hazard of large subduction thrust earthquakes at the Hikurangi subduction zone, New Zealand, New Zeal. J. Geol. Geophys. 41, 343-354.

Reyners, M., and D. Eberhart-Phillips (2009). Small earthquakes provide insight into plate coupling and fluid distribution in the Hikurangi subduction zone, New Zealand, Earth Planet. Sci. Lett. 282, nos. 1/4, 299-305.

Richmond, B. M., M. Buckley, S. Etienne, C. Chagué-Goff, K. Clark, J. Goff, D. Dominey-Howes, and L. Strotz (2011). Deposits, flow characteristics, and landscape change resulting from the September 2009 South Pacific tsunami in the Samoan islands, Earth Sci. Rev. 107, 38-51.

Rodgers, D., and T. Little (2006). World's largest coseismic strike-slip offset: The 1855 rupture of the Wairarapa fault, New Zealand, and implications for displacement/length scaling of continental earthquakes, $J$. Geophys. Res. 111, no. B1212408, doi: 10.1029/2005JB004065.

Round, F. E., R. M. Crawford, and D. G. Mann (1990). The Diatoms: Biology and Morphology of the Genera, Cambridge University Press, Cambridge, United Kingdom.

Sak, P., D. Fisher, T. Gardner, J. S. Marshall, and P. C. LeFemina (2009). Rough crust, forearc kinematics, and Quaternary uplift rates, Costa Rican segment of the Middle American Trench, Geol. Soc. Am. Bull. 121, nos. 7/8, 992-1012. 
Shennan, I., N. Barlow, G. Carver, F. Davies, E. Garrett, and E. Hocking (2014). Great tsunamigenic earthquakes during the past $1000 \mathrm{yr}$ on the Alaska megathrust, Geology 42, no. 8, 687-690.

Shennan, I., R. Bruhn, N. Barlow, K. Good, and E. Hocking (2014). Late Holocene great earthquakes in the eastern part of the Aleutian megathrust, Quaternary Sci. Rev. 84, 86-97.

Sieh, K., D. H. Natawidjaja, A. J. Meltzner, C.-C. Shen, H. Cheng, K.-S. Li, B. W. Suwargadi, J. Galetzka, B. Philibosian, and L. Edwards (2008). Earthquake supercycles inferred from sea-level changes recorded in the corals of West Sumatra, Science 322, 1674-1678.

Stirling, M., G. McVerry, M. Gerstenberger, N. Litchfield, R. Van Dissen, K. Berryman, P. Barnes, L. Wallace, B. Bradley, P. Villamor, et al. (2012). National Seismic Hazard Model for New Zealand: 2010 Update, Bull. Seismol. Soc. Am. 102, no. 4, 1514-1542, doi: 10.1785/0120110170.

Van Dam, H., A. Mertens, and J. Sinkeldam (1994). A coded checklist and ecological indicator values of freshwater diatoms from the Netherlands, Netherlands J. Aquat. Ecol. 28, 117-133.

Van Dissen, R., M. McSaveney, D. Townsend, G. Hancox, T. Little, W. Ries, N. Perrin, G. Archibald, G. Dellow, C. Massey, et al. (2013). Landslides and liquefaction generated by the Cook Strait and Lake Grassmere earthquakes: A reconnaissance report, Bull. New Zeal. Soc. Earthq. Eng. 46, no. 4, 196-200.

Vos, P. C., and H. de Wolf (1993). Diatoms as a tool for reconstructing sedimentary environments in coastal wetlands: Methodological aspects, Hydrobiologia 269/270, 285-296.

Wallace, L. M., and J. Beavan (2010). Diverse slow slip behavior at the Hikurangi subduction margin, New Zealand, J. Geophys. Res. 115, no. B12, B12402.

Wallace, L. M., P. Barnes, J. Beavan, R. Van Dissen, N. Litchfield, J. Mountjoy, R. Langridge, G. Lamarche, and N. Pondard (2012). The kinematics of a transition from subduction to strike-slip: An example from the central New Zealand plate boundary, J. Geophys. Res. 117, no. B2, B02405, doi: 10.1029/2011JB008640.

Wallace, L. M., J. Beavan, R. McCaffrey, and D. Darby (2004). Subduction zone coupling and tectonic block rotations in the North Island, New Zealand, J. Geophys. Res. 109, no. B12406, doi: 10.1029/2004JB003241.

Wallace, L. M., U. A. Cochran, W. P. Power, and K. J. Clark (2014). Earthquake and tsunami potential of the Hikurangi subduction thrust, New Zealand: Insights from paleoseismology, GPS, and tsunami modeling, Oceanography 27, no. 2, 104-117.

Wallace, L., M. Reyners, U. Cochran, S. Bannister, P. Barnes, K. Berryman, G. Downes, D. Eberhart-Philips, A. Fagereng, S. Ellis, et al. (2009). Characterizing the seismogenic zone of a major plate boundary subduction thrust: The Hikurangi margin, New Zealand, Geochem. Geophys. Geosyst. 10, no. 10, doi: 10.1029/2009GC002610.

Wang, X., and P. L.-F. Liu (2007). Numerical simulation of the 2004 Indian Ocean tsunami-Coastal effects, J. Earthq. Tsunami 1, no. 3, 273-297.

Williams, C. A., D. Eberhart-Phillips, S. Bannister, D. H. N. Barker, S. Henrys, M. Reyners, and R. Sutherland (2013). Revised interface geometry for the Hikurangi subduction zone, New Zealand, Seismol. Res. Lett. 84, no. 6, 1066-1073.

Wilson, K. J., K. R. Berryman, N. J. Litchfield, and T. A. Little (2006). A revision of Mid- to Late Holocene marine terrace distribution and chronology at New Zealand's most tectonically active coastal location, Pakarae River, North Island, New Zealand, New Zeal. J. Geol. Geophys. 49, no. 4, 477-489.

Witkowski, A., H. Lange-Bertalot, and D. Metzeltin (2000). Diatom Flora of Marine Coasts I, A. R. G. Gantner Verlag K. G., Ruggell, Lichtenstein.

Witter, R. C., H. M. Kelsey, and E. Hemphill-Haley (2003). Great Cascadia earthquakes and tsunamis of the past 6700 years, Coquille River estuary, southern coastal Oregon, Geol. Soc. Am. Bull. 115, no. 10, 1289-1306.

GNS Science

P.O. Box 30368

Lower Hutt, New Zealand

(K.J.C., U.A.C., W.L.P.)

Geomarine Research

19 Debron Avenue

Remuera

Auckland, New Zealand

(B.W.H., A.T.S.)

University of Texas

Institute for Geophysics

10100 Burnet Road (R2200)

Austin, Texas 78758

(L.M.W.)

Manuscript received 25 September 2014; Published Online 19 May 2015 